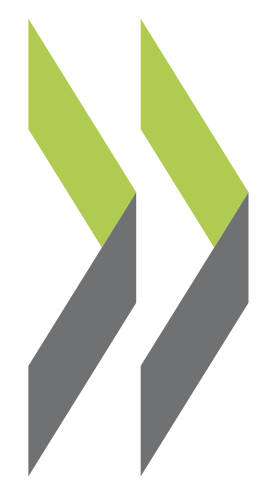

OECD Economics Department Working Papers No. 353

\title{
Macroeconomic Policy and Economic Performance
}

Pedro de Lima, Alain de Serres, Mike Kennedy 
Organisation de Coopération et de Développement Economiques

Organisation for Economic Co-operation and Development

30-Apr-2003

ECONOMICS DEPARTMENT

English text only

Cancels \& replaces the same document of 09 April 2003

MACROECONOMIC POLICY AND ECONOMIC PERFORMANCE

ECONOMICS DEPARTMENT WORKING PAPERS NO. 353

by

Pedro de Lima, Alain de Serres and Mike Kennedy 


\section{ABSTRACT/RÉSUMÉ}

\section{Macroeconomic policy and economic performance}

This paper analyses the major changes in both monetary and fiscal policy that have taken place over the past two decades and, within the limits of the existing empirical research, evaluates the overall costs and benefits for the OECD economies. The general findings for monetary policy are that, while it was costly to lower inflation (in terms of output and employment), there are also benefits in terms of lower risk premiums on interest rates, a more favourable investment climate and an improvement in economic efficiency. That said, the paper concludes that there is not much of a case for lowering inflation further from its already low level. While inflation was being lowered, in a number of cases central banks were also undergoing rather significant changes to their institutional structures and policy-making frameworks. There is some limited evidence that these changes have helped in terms of better anchoring inflation expectations. At the same time there is no firm answer on how best to respond to asset price developments beyond extracting whatever information they may contain about future economic developments. Despite recent slippage, fiscal policy has also contributed to a better macroeconomic environment through the restoration of automatic stabilisers, improved health of public finances and, importantly, by underpinning the reductions in real interest rates. The paper also examines the role of fiscal rules where there is not a clear consensus on the appropriate target or horizon for policy. It closes by noting that recently implemented fiscal frameworks may not be sufficient to guarantee sustainability over the medium term in the face of projected rising demands from health care and ageing.

Keywords: macroeconomic stabilisation; policy rules; disinflation; inflation target; fiscal consolidation; fiscal sustainability

JEL classification: E31, E52, E58, E61, E62

$* * * * *$

\section{Politique macro-économique et performance}

Cette étude examine les changements majeurs survenus au cours des vingt dernières années dans la conduite des politiques monétaire et fiscale et en évalue les principaux coûts et bénéfices sur la base de la littérature empirique existante. Concernant la politique monétaire, bien qu'il ait été coûteux de réduire l'inflation (en termes d'emploi et de production), il y eu également des bénéfices en termes de réduction de prime de risque sur les taux d'intérêt, un climat plus favorable à l'investissement et une plus grande efficience économique. Ceci étant, l'étude conclut qu'il n'apparaît pas justifié de poursuivre la désinflation au-delà des faibles niveaux déjà enregistrés dans la plupart des pays. Parallèlement à la poursuite de la politique désinflationniste, plusieurs banques centrales ont modifié de manière importante le cadre institutionnel dans lequel la politique est mise en opération. L'hypothèse selon laquelle ces changements ont contribué à mieux ancrer les anticipations inflationnistes bénéficie de quelques appuis empiriques, mais de façon indirecte et limitée. Par ailleurs, au-delà de l'extraction d'information qu'ils peuvent contenir sur l'évolution économique future, il n'existe pas de réponse claire et tranchée concernant la façon dont les autorités monétaires doivent mieux réagir aux mouvements du prix des actifs. Malgré les récents dérapages, la politique fiscale a également contribué à l'amélioration de l'environnement macro-économique via la restauration des stabilisateurs économiques, de l'amélioration de la santé des finances publiques et la réduction des taux d'intérêts réels. L'étude examine également le rôle des règles fiscales et souligne l'absence de consensus concernant le choix de la cible appropriée ainsi que de l'horizon sur lequel l'objectif doit être atteint. Il est noté qu'en dépit de ces changements, il n'est pas garanti que les politiques fiscales actuelles soient soutenables à moyen et long terme, compte tenu des pressions futures sur les coûts de santé et de retraite associés au vieillissement de la population.

Mots clés : stabilisation macro-économique, règles du politique, désinflation, cible d'inflation, consolidation fiscale, viabilité fiscale

Classification JEL : E31, E52, E58, E61, E62.

Copyright: OECD OECD 2003. All rights reserved.

Applications for permission to reproduce or translate all, or part of, this material should be made to: Head of Publications Service, OECD, 2 rue André-Pascal, 75775 PARIS CEDEX 16, France. 


\section{TABLE OF CONTENTS}

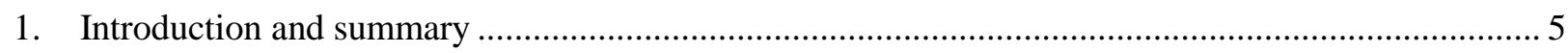

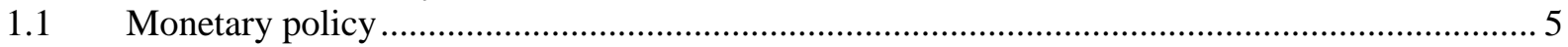

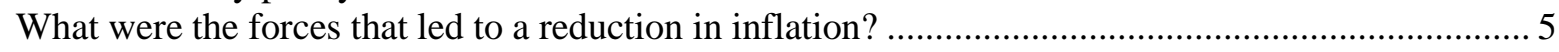

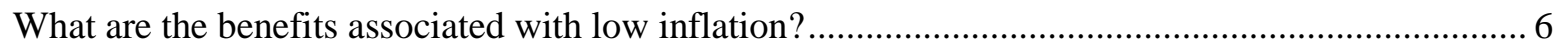

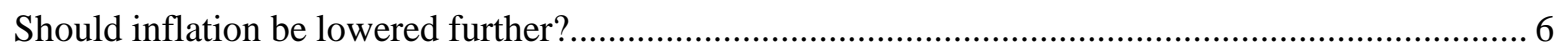

What has been the role of changes in central bank institutional frameworks and will these help to

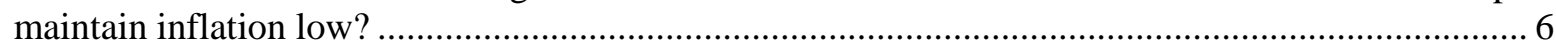

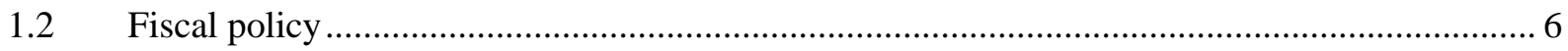

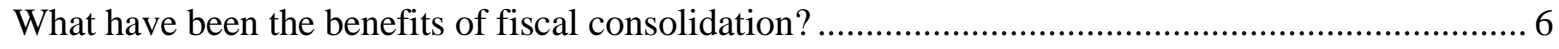

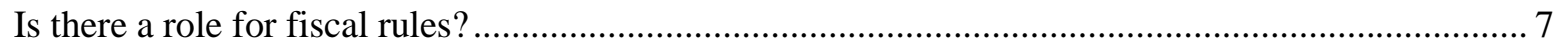

Are current fiscal positions sustainable in the long run? .............................................................. 7

2. The disinflation process over the past two decades ....................................................................... 7

3. The effects of low and stable inflation on the functioning of the economy ….................................... 8

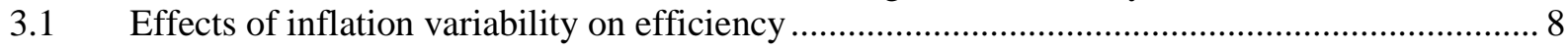

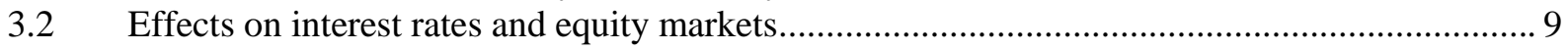

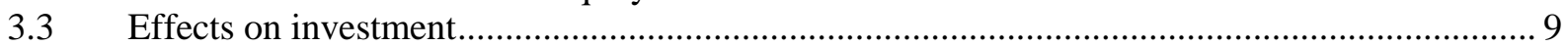

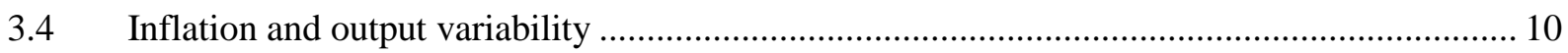

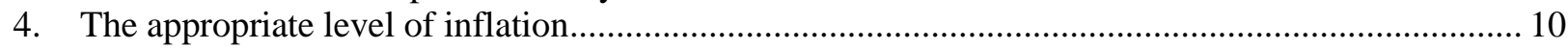

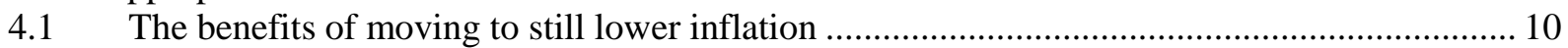

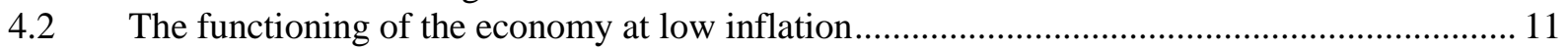

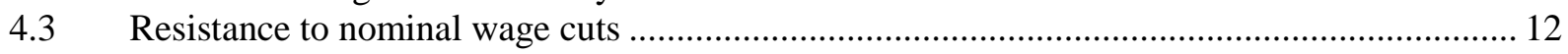

4.4 Policy challenges facing accession countries to the European Union .................................... 13

5. The role of institutional changes and credibility in keeping inflation low...................................... 14

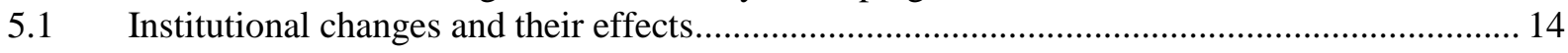

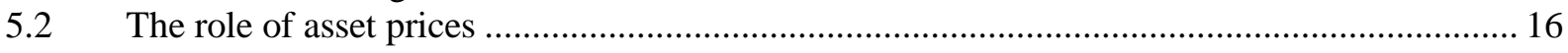

6. The contribution of fiscal policy to macro stability ................................................................... 18

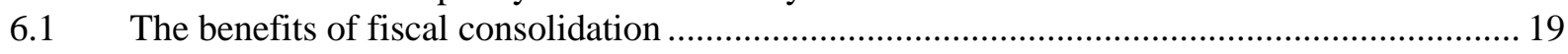

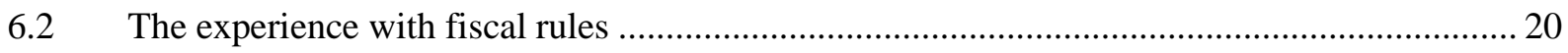

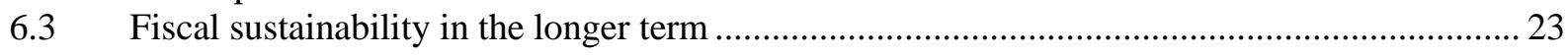

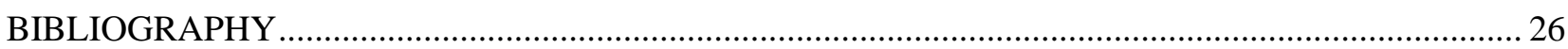


Tables

1. $\quad$ Estimated impact of inflation changes on output per capita

2. Real long-term interest rate equation

3. Estimated costs and benefits of reducing inflation two percentage points

4. The zero bound on interest rates

5. Downward nominal rigidities

6. Recent changes of institutional structures of central banks in selected OECD Member countries

7. Fiscal consolidations in selected OECD countries

8. The simulated impact of fiscal policy on the cyclical volatility of GDP

9. Changes in the fiscal framework in the 1990s in selected OECD Member countries

\section{Figures}

1. Inflation, oil prices, output gaps and inflation variability

2. Real long-term interest rates in major areas

3. Implied equity premium and trend inflation

4. Inflation volatility versus out put volatility

5. Cumulative output gap and core inflation in euro area countries

6. Inflation expectations implied from indexed bonds

7. Equity price indexes

8. $\quad$ Real housing prices

9. $\quad$ Fiscal balance positions and debt levels

10. Output gaps and the change in the government structural balance 
ECO/WKP(2003)7

\title{
MACROECONOMIC POLICY AND ECONOMIC PERFORMANCE
}

\author{
Pedro de Lima, Alain de Serres and Mike Kennedy ${ }^{1}$
}

\section{Introduction and summary}

1. The past two decades have witnessed significant changes in macroeconomic policy, with the orientation towards re-establishing and maintaining stability a defining feature. In particular, over this period, the goal of monetary policy became more narrowly focused on price stability while fiscal policy was increasingly directed towards restoring government financial balances to sounder and more durable positions. These changes reflected the widely held view that establishing an environment of macroeconomic stability contributes importantly to a better overall economic performance.

2. This paper characterises and analyses the major changes in macroeconomic policy that have taken place over the past two decades and, within the limits of data and existing empirical analysis, evaluates the overall costs that were involved as well as the benefits that resulted from these efforts. The analysis draws heavily on some previous OECD work but it is also based on a selective reading of the literature. The main results of this work are summarised here under a number of broad headings, which themselves serve as a road map to the paper.

\subsection{Monetary policy}

What were the forces that led to a reduction in inflation?

- Starting roughly two decades ago, there was a general commitment by policymakers to lower inflation from rates that were deemed both unacceptably high and at risk of becoming entrenched. The process, although helped by more favourable supply-side developments than in the previous period, nonetheless involved significant costs in terms of output and unemployment.

1. The authors are all members of the Money and Finance Division in the Economics Department of the OECD. They are grateful for valuable assistance from Cyn-Young Park and Gert Wehinger and wish to acknowledge helpful comments from Jean-Philippe Cotis, Mike Feiner, Jørgen Elmeskov, Michael Kiley, Peter Hoeller, Vincent Koen, Dave Rae and Paul van den Noord. They also thank Laure Meuro and Catherine Lemoine for statistical assistance, and Paula Simonin and Veronica Humi for secretarial assistance. 
What are the benefits associated with low inflation?

- The better inflation environment has been generally associated with reduced risk premiums that have contributed to real interest rates being lower than they might otherwise have been and improved equity returns. Based on previous OECD empirical work, lower inflation is estimated to have created a more favourable investment environment and, because of a tendency for inflation volatility to decline at the same time, an improvement in overall economic efficiency.

\section{Should inflation be lowered further?}

- There remains a debate as to what constitutes an appropriate level of inflation. Some have argued that the welfare and efficiency gains of moving inflation from already low levels to close to zero are significant, although this remains controversial. On the other hand, the existence of the zero-floor on nominal interest rates and a documented resistance of workers to accept (and managers to implement) nominal wage cuts raise concerns about the viability of the economy at close to zero inflation. Those who hold this view also maintain that the present (low) rates do not distort relative price signals in a way that induces an inefficient allocation of resources. Given its already low level, the case for further reductions in inflation goals is not overly strong.

What has been the role of changes in central bank institutional frameworks and will these help to maintain inflation low?

- There have been a number of changes to both the institutional structures (perhaps the most dramatic being the creation of the European Central Bank and the introduction of the euro) as well as to the policy frameworks of central banks and, for the most part, these occurred during the second disinflation period in the 1990s. In several cases, mandates were strengthened and given a clearer focus on price stability. A significant number of OECD countries adopted either explicit or implicit numerical inflation targets, and in the former case, typically in consultation with governments. An integral part of this new policy strategy is increased transparency and accountability. This in turn has led to more emphasis on communications. There is some tentative evidence that the new frameworks have led to more firmly anchored inflation expectations. Track records, however, are still relatively short. There is no firm consensus on how best to respond to asset price developments beyond extracting whatever information they may contain about future economic developments.

\subsection{Fiscal policy}

What have been the benefits of fiscal consolidation?

- Throughout the 1990s, the vast majority of OECD countries (Japan being a notable exception) reduced or even eliminated general government deficits and put debt-to-GDP ratios on a downward path. While this implied in several cases pro-cyclical fiscal tightening, there were also clear benefits. First, it underpinned the reduction in real interest rates that contributed to the period of improved economic growth in the late 1990s. Second, by restoring the health of public finance, fiscal consolidation may have reinforced the credibility 
of monetary policy, even though the evidence is difficult to establish. Third, it has put countries in a better position to allow automatic stabilisers to fully operate over the business cycle.

\section{Is there a role for fiscal rules?}

- The variety observed in the design of rules partly reflects the lack of a clear consensus regarding what the appropriate target should be (the level of debt, deficit or expenditures), whether it should be satisfied at all times or only over a defined horizon (e.g. the business cycle) and whether specific items (e.g. public investment) should be excluded from the target definition. In all cases, arguments based on economic efficiency should be evaluated against practical considerations.

\section{Are current fiscal positions sustainable in the long run?}

- Some evidence suggests that even the recently implemented fiscal frameworks will not be sufficient to guarantee long-term fiscal sustainability, as the pressure to lower tax burdens could increasingly conflict with rising health care and pension costs resulting from demographic changes. These assessments, however, depend on projections of economic developments over very long time horizons that will not necessarily be good approximations to the actual outcomes. However, even if fiscal scenarios are sustainable on an accounting basis, they could nonetheless be unsustainable politically if, for example, they were to imply pensions at poverty levels or too large a tax burden for future generations.

\section{The disinflation process over the past two decades}

3. After the double-digit rates of the 1970s and the very early 1980s, a long period of disinflation ensued in the OECD area (Figure 1). There were some favourable supply shocks that aided the process. Throughout the first half of the 1980s, there was a reversal of the oil-price increases that had plagued the previous decade; despite some fluctuations, they were not a source of inflation pressures between the mid1980s and the late-1990s. Later in the process, heightened competition resulting from increasingly open markets $^{2}$ and structural changes following deregulation of the labour and product markets ${ }^{3}$ in some countries, might have been translated into lower price pressures. For the United States, an increase in productivity growth starting in the middle of the 1990s was an additional factor, although its effect will be transitory. ${ }^{4}$

\section{[Figure 1. Inflation rates, oil prices, output gaps and inflation variability]}

4. In a large number of countries, low inflation rates were adopted by central banks as either the primary goal or were given added prominence. In principle, this increased commitment on the part of policymakers to price stability, to the extent that it improved credibility that in turn led to lower inflation expectations, should have moderated actual price increases as well. In practice, however, many of these

2. The reduction in the degree to which firms "pass through" both price and cost increases due to exchange rate movements or other factors is sometimes interpreted as a result of heightened competition. See Brayton et al. (1999); Taylor (2000) and Wadhwani (2001).

3. Pigott and Christiansen (1998) document a number of these reforms.

4. Staiger et al. (2001), provide some empirical evidence for the US economy supporting this view. 
changes to frameworks occurred in the 1990s and hence may play a more significant role in keeping inflation low than they did in bringing it down.

5. To a very large extent, the declines in inflation came at the expense of lost activity as measured by the OECD estimates of output gaps. Looking at crude "sacrifice ratios", the costs of disinflation were positive everywhere over the two decades with little systematic variation across countries and between the two decades. The costs, in terms of lost employment and output, would have been amplified to the extent that some form of hysteresis was operating (Blanchard and Summers, 1986 and Ball, 1997), i.e. insofar as there was a tendency for the NAIRU to rise with actual unemployment rates. While the empirical evidence seems to contradict the extreme form of hysteresis (Richardson et al., 2000), NAIRU estimates did rise in a number of countries, particularly those in Europe, during the 1980s, as unemployment rates increased.

\section{The effects of low and stable inflation on the functioning of the economy}

6. High and variable inflation can have detrimental effects on economic efficiency. It can also impair the functioning of debt and equity markets, and partly through these channels, have negative effects on investment. The evidence presented below does suggest that lowering inflation has contributed to improving the economic climate for growth and investment.

\subsection{Effects of inflation variability on efficiency}

7. High inflation is often associated with increased inflation variability. There are a number of explanations for this relationship not all of which imply causation. For example, during the 1970s, oil price changes likely explain part of the correlation. More generally, high inflation may lead to higher variability if the (short-term) Phillips curve were more steeply sloped (possibly due to the existence of menu costs, Ball et al., 1988), or prone to shifting more quickly in that range, making it more sensitive to changes in economic conditions.

8. The variability of inflation adds noise to capital markets, with repercussions on the choice of investment projects and thereby multi-factor productivity. In addition, the functioning of the price mechanism more generally can be disrupted, leading to distortions and resource misallocation as economic agents face difficulties distinguishing between permanent and transitory price changes, as well as between relative and overall price level changes.

9. While some studies have raised doubts about a negative association of the variability of inflation with growth, earlier work by the OECD has provided empirical support for the notion. ${ }^{5}$ The results proved to be robust to a number of specifications. Based on these estimates, the reduction in inflation variability in the 1990s compared with the 1980s has led to a general improvement in per capita growth in all countries where it occurred (Table 1). For example, the average drop in variability for the OECD countries studied was about two-thirds of a percentage point and this, over time, could have raised per capita output by an estimated 1.3 per cent.

[Table 1. Estimated impact of inflation changes on output per capita]

5. See OECD (2000) and Bassanini et al. (2001). The pooled regression analysis also controls for fiscal policy and other variables. 


\subsection{Effects on interest rates and equity markets}

10. Uncertainty created by higher inflation could lead to an increase in the risk components of longer-term interest rates, since debt instruments are generally not indexed. Earlier work by the OECD, dating back to the mid-1990s, drew attention to a positive relationship between real interest rates and inflation, as well as other determinants, most notably the fiscal balance (Table 2). ${ }^{6}$ During the first half of the 1990s, countries that had had a poor track record on controlling inflation tended to have higher real interest rates compared with those prevailing in the United States, which were used as a benchmark. Over the past two decades there has been a tendency, although not overly marked, for the level of real interest rates to drift down (Figure 2) as inflation has fallen and particularly as fiscal balances have improved.

\section{[Table 2. Real long-term interest rate equation]}

\section{[Figure 2. Real long-term interest rates in major areas]}

11. A second and somewhat more controversial effect of high inflation is on equity markets. Empirically, the risk premium, measured as the difference between the earnings-price ratio and the real rate of interest, ${ }^{7}$ has tended to move down with trend declines in inflation in the major equity markets and with it the cost of raising equity capital (Figure 3). The relationship reflects the fact that equity prices rose much faster than earnings when inflation fell. That being said, the result is puzzling since holding equities should have been a good hedge against inflation, implying a much weaker relationship if any at all. Some have ascribed this effect to distortions caused by a non-indexed tax system and its effect on the return to business investment (Feldstein, 1980), while others put more weight on the increased uncertainty that market participants have to deal with in conditions of high inflation. In this latter view, it has been argued that both expected and unexpected increases in inflation are accompanied by drops in stock returns (Boudoukh et al. 1994), possibly because of an increased probability of counter-cyclical monetary policy (Sharpe, 2002). The relationship, however, is also consistent with other hypotheses. For example, investors may have mistakenly discounted future earnings using nominal interest rates (Modigliani and Cohn, 1979) or that they may have failed to incorporate inflation properly into their earnings projections (Sharpe, 2002).

[Figure 3. Implied equity premium and trend inflation]

\subsection{Effects on investment ${ }^{8}$}

12. To test for the effects of lower inflation on investment, two approaches present themselves both of which have been employed by the OECD. In one, investment equations for a limited number of countries were estimated as functions of real GDP, the cost of capital and measures of financial market development (OECD, 2001 and Pelgrin et al., 2002). Over the period 1995-1999, the fall in the cost of capital and the increase in stock market capitalisation contributed positively to investment. It should be noted that, despite the above-mentioned effects on the real interest rate, by far the most important contributor to the drop in the cost of capital was the decline in the price of investment goods relative to the GDP deflator.

6. See Orr et al. (1995), who also identified a number of other factors that affect real interest rates, notably the general government fiscal balance.

7. For similar calculations for the US equity markets, see Nordhaus (2002).

8. Inflation also can potentially affect saving; however, empirical evidence is clouded by measurement problems suggesting that any estimated relationship could be spurious. 
13. In the other approach, (OECD, 2000 and Bassanini et al., 2001), inflation was entered directly into an investment equation and was found to have a negative, and significant, impact. The equation also controlled for private credit, trade exposure as well as various measures of government spending and taxation. In addition, the results were found to be robust across a variety of specifications. On the other hand, inflation variability was found to be insignificant in various specifications.

\subsection{Inflation and output variability}

14. A feature of the current period of low inflation is that the variability of GDP growth has declined as well (Figure 4). At the least, these results suggest that the maintenance of price stability has not come at the expense of added output variability. However, again, part of the decline in each reflects other factors. For example, there has been an absence of large external shocks to inflation as well as a number of structural developments that have led to lower output variability. ${ }^{9}$ Nonetheless, the greater commitment of central banks to achieving and maintaining price stability may have also played a role.

[Figure 4. Inflation volatility versus output volatility]

\section{The appropriate level of inflation}

15. With the move to lower and more stable inflation, and the reaping of the associated gains, the debate has shifted to what should be its appropriate level, with the focus being on what are the benefits of moving from low to zero inflation or, in the extreme case, a fixed price level, versus the difficulties of operating in that environment. These are taken up in the next two subsections.

\subsection{The benefits of moving to still lower inflation}

16. A number of studies have attempted to measure the distortions and welfare losses that even low inflation (say 2 per cent, adjusted for biases) can introduce (Table 3). These arise through the same channels as the gains from moving to low inflation. While it is reasonable to expect that diminishing returns to any potential benefits would be encountered as inflation rates moved lower, the gains could still be significant, given the existence of an already distortionary tax system (Feldstein, 1997). Some estimates show the gains to be sizeable, and since they are permanent, they would outweigh the costs of typical disinflations (Ball, 1994), which are temporary.

\section{[Table 3. Estimated costs and benefits of reducing inflation by two percentage points]}

17. There is a need for some caution in interpreting these estimated gains, as they are for the most part derived using partial equilibrium analysis. In addition, the results are sensitive to the assumptions regarding a few key parameters such as the interest elasticity of saving as well as the discount rates used to compute the present values of future gains (Fischer, 1999). In practice, most central banks have not pursued inflation rates close or equal to zero.

9. For example, the growth in the importance of the service sector as well as better management of inventories, see Dalsgaard et al. (2002), for an analysis in the context of business cycles, and also OECD (2002). 


\section{2}

The functioning of the economy at low inflation

18. Opponents, apart from questioning the extent of the distortions that arise at low inflation, have focussed on the fact that the adoption of full price stability would increase the probability of deflation, with all of its attendant problems. ${ }^{10}$ In the event, because of the zero interest rate floor, the ability of the authorities to respond would be very limited. In this respect, the adoption of a positive, but low, inflation goal can be understood as an insurance policy against such an eventuality (Summers, 1991).

19. The merit of that argument depends on both how frequently negative real rates may be required to re-equilibrate the economy as well as on an assessment of the likelihood that the zero-bound in interest rates could be encountered. On the first issue, while ex post real rates have turned negative on a number of occasions during the past thirty years, ${ }^{11}$ what matters for agents are ex ante real rates. Some calculations of such real rates ${ }^{12}$ suggest that they have never been negative for the euro area and the United Kingdom. For the United States, on the other hand, they have been negative twice over the past two and a half decades. The first such episode occurred during the late 1970s, when the authorities eased the stance of policy but, in the face of rising inflation, this was quickly reversed. The second was for a very short spell in 1993 when the US economy was facing "financial head winds" and this, while also short-lived, was likely helpful. In each case the period during which real interest rates were negative was very short.

20. A number of studies have tried to assess the likelihood of the zero-lower-bound on interest rates becoming binding for different rates of target inflation (Table 4). Taking account of the fact that models of the monetary transmission mechanism used to simulate these probabilities are at best a rough approximation of what is a complex process, the overall likelihood that interest rates would hit the zero bound appears to be significant at very low rates of inflation. Given the potential costs associated with deflation, these results provide some support for the view that it might be prudent not to attempt to drive the inflation rate too close to zero. Moreover, the results also indicate that in a low inflation environment, the prompt response of monetary authorities can have a substantial impact on the final outcome. Indeed, there is some evidence, again based on simulation exercises, that more prompt and decisive action by the monetary authorities can be both output and inflation stabilising, while preventing interest rates from hitting the zero-bound (Ahearne et al., 2002 and King, 2000).

\section{[Table 4. The zero-bound on interest rates]}

21. The case of Japan is often held up as an illustration of the dangers of falling into chronic deflation. While Japan's problems probably mainly arise from a malfunctioning monetary transmission mechanism, it has also been argued that they are related in part to a lack of promptness in monetary policy reaction after the collapse of the bubble in the early 1990s (Ahearne et al., 2002). Although the existence of a zero interest rate bound serves as a significant complicating factor for the conduct of monetary policy, in the case of Japan it has been noted that there are alternative channels through which monetary policy can influence economic activity. ${ }^{13}$ All of these, however, are not as controllable as short-term interest rates, the

10. A price-level target would imply that the authorities should aim for reductions in prices in the wake of positive shocks.

11. In several instances, particularly during the 1970 s, these were considered as policy mistakes that in turn over-stimulated demand.

12. Assuming a unitary inter-temporal elasticity of substitution, Viñals (2001) constructs series for the euro area and the United States between 1980 and 2000 from the first-order equilibrium condition for consumption. Using the Livingston survey and the Gallup survey, King (1999) estimates one-year real interest rates for the United States (1954-1998) and the United Kingdom (1984) economies, respectively.

13. An automatic mechanism that has been considered as a possible way out of the zero lower bound is the "real balance effect", first popularised by Pigou. In a more updated version, as prices decline, holders of 
main instrument of the central bank. For example, a potentially powerful one is the exchange rate, ${ }^{14}$ although engineering effective currency depreciation through intervention is difficult, in good part because the workings of these markets are not well understood. The central bank can also intervene directly in the markets for debt (private as well as government) as well as for equities. ${ }^{15}$ Nonetheless, there are problems associated with such a policy, beyond the fact that it would lie outside typical mandates. Thus, such action may create moral hazard by bailing out banks; it may affect relative prices of assets and thereby interfere with market allocation of capital; if not well understood within the general policy framework, it may undermine credibility; and it transfers market risk to the balance sheet of the central bank. In addition to these channels, Meltzer (2000) suggested that the current deflationary forces in the Japanese economy would dissipate if the rate of money growth were temporarily increased until the excess demand for money turned into an excess supply. Finally, a number of observers have emphasised the importance of credible inflation targets but, while in principle such a target might help to anchor expectations, credibility is difficult to gain or to sustain once the central bank's main instrument reaches the zero floor.

\subsection{Resistance to nominal wage cuts}

22. In an influential paper, Akerlof et al. (1996) have advocated the maintenance of a level of inflation above that which most central banks are pursuing, either explicitly or implicitly, as a way to "grease the wheels" of the labour market. The argument is that, due to money illusion, workers are reluctant to accept nominal wage cuts since they are perceived as "unfair". Employers, for their part, are also reluctant to enact them because of concerns about damaging workers "morale" and productivity. There is, however, less resistance to real wage declines that result from inflation. Accordingly, in the absence of inflation, aggregate real wages, in addition to nominal wages, become rigid. This is particularly so in circumstances of slow productivity growth. There are institutional factors at play here as well, including the number of layers of contracts that require re-negotiation, the coverage of collective agreements, the legal framework of contract renegotiations and the strictness of the employment protection legislation for non-union workers (Holden, 2002). ${ }^{16}$

23. Several studies have provided some support for the nominal wage rigidity hypothesis in a variety of countries (Table 5). The distribution of nominal wage changes tends to be asymmetrically distributed (negative wage adjustments are few compared with positive ones) with typically a large spike at zero. While this spike is commonly interpreted as evidence of asymmetric downward wage rigidities, Smith (2000), using UK survey data, provides evidence that a significant part of those zero wage changes can be attributed to "symmetric" causes such as long-term contracts, measurement error and rounding. At an aggregate level, some studies (including, Card and Hyslop, 1997) find evidence that the overall impact of these nominal wage rigidities on economic activity is modest.

government debt will witness an increase in their wealth levels that, in the absence of pure Ricardian equivalence, might boost economic activity (Fuhrer, 2001).

14. A recent proposal for getting Japan out of its current deflation consists of depreciating the nominal exchange rate by purchasing foreign exchange (McCallum, 2000 and Svensson, 2001). Others have pointed to the difficulty of "engineering" such a change in a currency's value (Krugman, 1998 and Christiano, 2000).

15. Recently, the Bank of Japan announced that it will purchase shares directly from banks, with the goal of removing from the bank balance sheets amounts in excess of Tier 1 capital requirements.

16. Akerlof et al. (2000), explore this view in a more recent paper. See also Fortin (1996), Bewley (1999) and Howitt (2002) for a discussion of how wage rigidities can be related to morale and fairness considerations. 
24. While inflation may have "grease" effects that help offset nominal downward wage rigidity, it also has "sand" effects (Groshen and Schweitzer, 1997). These arise because of errors associated with increased uncertainty, as well as from nominal rigidities associated with menu costs and timing constraints. Evidence for both types of effects is found; however, at levels up to 5 per cent inflation, the net impact on unemployment is not statistically significant.

\section{[Table. 5 Downward nominal rigidities: Summary of findings in the literature]}

25. Although these studies provide useful insights into the workings of labour markets, two caveats are worth mentioning. First, it could be argued that once inflation has been low for a long time, and is expected to remain so, notions of fairness will change and with it the reluctance to accept nominal wage reductions. Second, overall wage reductions can be achieved as individuals change jobs or as employers change the composition of their workforce, although here the overall effect could be ambiguous. For example, cost reductions could come at the expense of lower productivity.

26. Within monetary unions, different adjustment mechanisms in individual members may work against maintaining zero inflation. For example, recent inflation pressures in the euro area have seemed to be persistent as some of the larger, slower growing economies have not generated sufficient disinflation pressures since 1998 to offset the increases observed in the faster growing Member economies (Figure 5). ${ }^{17}$ To the extent that this reflects asymmetries in the adjustment mechanism at low levels of inflation, it could result in the need to maintain excessive slack in order to keep area-wide inflation at a level consistent with price stability over the medium term. Related to this, it is possible that because of nominal floors to price and wage changes, relative price changes will become more difficult at low levels of inflation. ${ }^{18}$

\section{[Figure 5. Cumulative output gap and core inflation in euro area countries]}

\subsection{Policy challenges facing accession countries to the European Union}

27. For economies currently heading toward full membership of the European Union and, concomitantly, of the Economic and Monetary Union, ${ }^{19}$ the goals of price stability, coupled with the requirements of participating in ERMII, could be complicated by catching-up factors such as the so-called "Balassa-Samuelson" effect. With high capital mobility and the opening up of markets, the traded-goods sectors of these economies experience fast productivity growth and rapid wage gains. When these, in turn, spill over into the non-traded sector, it leads to upward pressure on prices there and a persistent, positive inflation differential relative to the European Union. ${ }^{20}$ While inflation rates have dropped significantly over

17. For example, Sinn and Reutter (2001) argue that at present for Germany's inflation rate to be 1.5 per cent, the euro area inflation target would have to be at least of the order of 2.5 per cent, implying an average inflation rate of close to 3 per cent for the other 11 members.

18. Such changes are needed in a monetary union that lacks alternative adjustment mechanisms, in order to deal with asymmetric shocks.

19. To meet the accession requirements, these economies are undertaking substantial reforms aimed at narrowing the gap that currently separates them from the European Union. While this process of real convergence takes place (an overall adjustment that includes convergence in output per capita levels as well as in wage and price levels), these countries achieve nominal convergence (the adjustment of nominal variables to threshold values defined by the Maastricht criteria) before full membership of the Economic and Monetary Union.

20. Increases in demand for non-tradeables and changes in the patterns of government consumption can also partially explain the inflation differentials vis-à-vis the EU (Corriceli and Jazbec, 2001). In addition, traded 
the past few years, to levels close to the EU average, it may be difficult for accession countries to combine nominal exchange rate stability with the inflation performance required to proceed towards monetary union, at least for some time.

28. The existing monetary policy frameworks in transition countries may also come under pressure from capital flows. All of the OECD Central European economies currently target inflation, although the approach to exchange rate management differs. ${ }^{21}$ With a symmetric 15 per cent band, the Hungarian exchange rate regime is the closest in spirit to ERMII, and therefore might serve as an indication of what would be the typical behaviour of inflation target regimes during the transition period to EMU. Although this new exchange rate regime has worked well since its implementation in May 2001, previous experience shows that under full capital mobility the maintenance of separate targets for inflation and the exchange rate (even if in a reasonably large band) can be difficult at best. Where two targets conflict, it is not easy to say which way policy should lean. As discussed above, inflation fluctuations carry real costs but so do the potentially substantial relative price fluctuations that can result from instability of the nominal exchange rate. Moreover, participation in ERMII upon accession would raise the risk of speculative attacks, because EU accession will likely coincide with the full liberalisation of capital accounts (Buiter and Grafe, 2002).

29. The future enlargement of the euro area also raises some policy questions for its current participants. Besides a number of institutional changes that will have to be introduced to better accommodate the enlarged membership, there are also some concerns about the impact of an expanded EMU for monetary policy. Nonetheless, the relative economic weight of the prospective members is quite small, and whether experiencing "Balassa-Samuelson" effects or not, they will not have a large influence on area-wide inflation.

\section{The role of institutional changes and asset prices for monetary policy}

\subsection{Institutional changes and their effects}

30. Starting in the early 1990s, there have been significant changes to the institutional structure of central banks as well as frameworks governing monetary policy (Schich and Seitz, 1999) and these have now spread to the vast majority of OECD countries. ${ }^{22}$ The general theme underlining all of these changes has been the establishment of price stability as the primary goal of the central bank (Table 6) ${ }^{23}$ At the same time, there has been a recognition that central banks need a certain amount of independence in order to achieve their now clearer (and in several cases, narrower) mandates. While the degree of this independence varies across OECD countries, at a minimum, most have instrument independence: that is, the freedom to use the monetary instrument to achieve the objective without political interference. Granting instrument independence to the Bank of England (in May 1997) had a pronounced positive effect on both bond markets and measures of inflation expectations. Among G7 central banks, the ECB stands as the only

goods have experienced some trend appreciation (Erceg, 2002). For recent empirical work on Balassa-Samuelson effects in Central and Eastern European countries, see Kovács (2002).

21. Hungary targets a central rate for the forint against the euro with a 15 per cent fluctuation band on either side. The Czech Republic and the Slovak Republic both have adopted managed floats while Poland has opted for a free floating regime.

22. Note that the National Bank of Poland has had instrument independence since 1989.

23. The relatively scant evidence available suggests that focus on price stability seems to have found favour with the general public. Importantly, once it has been reduced, there is distaste for inflation, which is perceived as harmful to standards of living (Shiller, 1997). 
institution that has been granted goal independence in the sense of defining the target associated with its mandate to pursue price stability.

\section{[Table 6. Recent changes of institutional structures of central banks in selected OECD Member countries]}

31. In line with increased independence, there have been important changes to central bank transparency regarding key aspects of the operation of monetary policy. While increased transparency is seen as filling a perceived "democratic deficit" (Briault et al., 1996) it also has the potential to increase the effectiveness of policy (Freedman, 2001). The type of information that central banks release to the general public, and financial markets in particular, has been categorised into various types and two are considered here: information that is aimed at engendering trust and that aimed at increasing the predictability of policy (Posen, 2002).

32. Central banks not only release information on the nature of the policy regime but also the numerical target (where it exists), the reasons why they may have missed the target and what they will do to meet it. This communication about their longer-run goals is aimed at increasing trust, which in turn should enhance flexibility in the sense of providing the central bank with more scope to change interest rates in the case of both demand or supply shocks. One testable implication should be a reduction in the persistence of inflation, which has occurred in a number of countries (see below). As well, in response to supply shocks, such trust should allow central banks to lower interest rates, if that is deemed appropriate. The available evidence lends support to this effect, particularly for inflation-targeting countries (Kuttner and Posen, 2001).

33. A number of central banks also make public details on their forecasts and on their models, as well as specific information on the reasons behind various decisions. The goal here is to remove noise from markets. Several central banks have taken significant steps in this direction. In terms of publishing forecasts (albeit with large confidence bands) of inflation and of GDP growth, the Bank of England, the Swedish Riksbank and the Reserve Bank of New Zealand have arguably gone the furthest. As well, almost all central banks publish explanations of recent policy decisions and some also announce bands between which key policy rates are expected to fluctuate. The limited empirical evidence on this suggests that there has been a reduction in the volatility and an increase in the predictability of interest rates (Posen, 2002).

34. If, as a result of these changes as well as the experience of lowering inflation itself, there has been an increase in central banks' credibility, the costs of, or indeed the need for, future disinflation will be reduced. In such a case, agents will tend to put more weight on the central banks' inflation objectives in forming expectations. While measuring inflation expectations is fraught with problems, rough measures, derived from indexed-linked bonds where they are available, have all fallen and are in line with explicit or implicit inflation objectives (Figure 6). That being said, there is only limited and, at best, tentative other evidence that credibility has been improved (see Box).

[Figure 6. Inflation expectations implied from indexed bonds] 


\section{Box. The impact on credibility}

While studies have not documented any evidence that sacrifice ratios have fallen (Andersen and Wascher, 1999), a recent study of Phillips curves for 17 OECD countries (Laxton and N'Diaye, 2002) found that the out-of-sample forecasts were improved if inflation expectations were modelled as partly forward looking compared with the standard backward-looking alternative, generally employed. The weight on the forward-looking component was modelled as a function of a proxy for credibility that varied over time. However, the difference in accuracy is not particularly large except in the cases of the United Kingdom, Sweden, Denmark and, to a lesser extent, the Netherlands and Belgium. In other work, the estimates of the NAIRUs for Canada and Greece were lowered and their statistical precision was improved when allowance was made for official or implicit inflation targets in constructing measures of inflation expectations (Richardson, et al., 2000).

Some researchers have looked at what has happened to the persistence of inflation as an indirect measure of credibility. The evidence on whether it has lessened is not overly robust. Declines observed in the United States and the United Kingdom in the late 1990s have been documented by Taylor, 2000 and Wadhwani, 2002, respectively. However, for the case of the United States, more sophisticated methods were not able to confirm a change over the past three decades (Pivetta and Reis, 2002).

Various studies that have analysed cases of inflation over-prediction in the late 1990s have found that a contributing factor has been the surprisingly low pass-through of import prices relative to earlier episodes. This was particularly noticeable in inflation-targeting countries such as Canada, Australia and New Zealand that have also experienced substantial currency depreciation prior to, or during, the period. A reduction in pass-through of import prices has also been found in the cases of the United Kingdom and Sweden based on event studies of the 1992 depreciation in both countries (Cunningham and Haldane, 1999). At the same time, these countries also had large output gaps. As well, there is evidence that the power of firms to pass on cost changes into higher prices has fallen and this may partly reflect an intensification of competitive pressures in domestic markets rather than an increase in credibility. ${ }^{1}$

1. See Taylor (2000) and Wadhwani (2002) for the United States and the United Kingdom respectively.

\subsection{The role of asset prices}

35. Although inflation has been brought down and there is a high degree of price stability almost everywhere in the OECD area, it has not been accompanied by asset price stability. The sharp rise in equity and house prices, particularly over the second half of the 1990s, and the large declines in those of equity starting in early 2000 (Figures 7 and 8), coupled with earlier experiences of large asset price changes, have raised questions as to the appropriate response of monetary policy.

\section{[Figure 7. Equity price indexes]}

\section{[Figure 8. Real housing prices]}

36. At one level, central banks have to look at asset price movements and take into account their potential implications for the inflation outlook. Indeed, a number of studies have documented that housing and equity prices, as well as exchange rates, do contain useful information about future prices and demand developments. ${ }^{24}$ The real question, thus, is whether monetary policy should go further than this and aim to influence asset prices. Theoretically, the argument has been advanced that since assets are vehicles for the

24. Cecchetti et al. (2000), document a number of these studies. See as well, Goodhart and Hofmann (2000). 
inter-temporal transfer of purchasing power, their fluctuations should enter the central bank's inflation target (Alchian and Klein, 1973 and Cecchetti et al., 2000). In practice, however, this argument has played no role in policy formulation.

37. A more practical reason for directly trying to influence asset prices is that these can become mis-aligned with potential for adverse effects once a correction occurs. In particular, the deflating of an asset price bubble risks causing systemic problems in the financial sector. Historically, large and sustained asset price reversals have been the most damaging when the banking sector had become overly involved during the "bubble period", situations not confined to just Japan (Edey and Hviding, 1995). Recently, concerns have been raised about the viability of insurance firms and pension funds that had become very exposed to equity. More generally, balance sheets throughout an economy may be damaged in the wake of large falls in asset prices and dealing with the associated negative impacts on activity and inflation may be a challenge for monetary policy.

38. The policymaker's problem is compounded when asset price surges occur against a background of low or even falling inflation and improving underlying economic conditions. In this case, provided it cannot be excluded that asset prices reflect fundamentals, a tightening of policy risks interrupting not only an expansion when inflation pressures were absent but also a move of demand towards a higher level of supply. In practice, it is difficult to determine if asset prices are being overly influenced by non-fundamentals (Greenspan, 2002). Nonetheless it is possible to say something. There are, for example, well-known and widely used measures of the appropriateness of asset prices. These can, at the very least, be used to make inferences that in turn allow the debate to be framed in terms of historical relationships (OECD, 1998; Borio and Lowe, 2002; and Kennedy et al., 1998). Indeed, while it will always be difficult to establish with a high degree of confidence what is behind an asset price movement, this is similar, in principle, to the uncertainty a forward-looking monetary policy will have to deal with in targeting price stability.

39. A crucial element in dealing with systemic risk that can follow a sharp correction in asset prices is a strong prudential framework. Indeed, if bursting a bubble requires very large interest rate increases, an alternative may be to let the bubble run its course and minimise the damage from the eventual collapse by ensuring that financial institutions and markets are sufficiently robust to withstand a large shock (Bernanke, 2002). As regards the banking sector, there are concerns that the regulatory capital requirements set under the 1988 Basle Committee Capital Accord might not provide adequate protection against an abrupt market downturn and an associated substantial increase in loan losses. In part, this is due to the growing sophistication of risk management techniques that have allowed banks to gradually increase the riskiness of their portfolio for given capital requirements.

40. Under the proposed new Capital Accord (referred to as Basle II) capital requirements will be more closely aligned with the risk taken by individual banks, largely by the widespread use of more flexible and sophisticated rating methods to provide risk weights. ${ }^{25}$ It is hoped that the improved matching between capital requirements and individual banks' risk positions will enhance the trade-off between costs and stability of the banking system, especially given that under the proposed accord, off-balance sheet activities would be included in the credit risk assessment framework.

41. However, one of the implications of the closer alignment of capital requirement with marketsensitive risk assessment may well be an amplification of the pro-cyclical impact of prudential regulation. The main reason is that models typically used to provide market-based evaluation of borrowers'

25. This involves both greater use of banks' own risk assessment especially in large banking organisations, coupled with supervisory authorities playing a more active role in validating the bank's internal rating methods as well as in judging overall whether the capital position is consistent with the risk profile. 
probability of default (value-at-risk models) are often adaptive in that they rely on previous history with the focus on a very short time horizon. As a result, rating systems tend to put excessive weight on borrowers' current conditions and usually fail to properly take account of the cyclical nature of default risk (Lowe, 2002). This, combined with the tendency for large banks facing growing competitive pressures to hold increasingly similar positions, raises the likelihood of a credit crunch in a downturn as a large proportion of banks try simultaneously to preserve their capital requirement (Persaud, 2000).

42. One way to limit the pro-cyclicality of risk assessment would be for supervisors to ensure that ratings are based on longer-term average probabilities of default, which would reduce the volatility of the weights used in the calculation of the capital ratio. However, the implementation of such solutions might be constrained, at least in the short run, by the availability and adequacy of data (ECB, 2001). The potential pro-cyclicality of the proposed Capital Accord could also be reduced by changing banks' provisioning practices towards a more dynamic, forward-looking approach. The principle would be to oblige banks and other deposit institutions to set provisions on the basis of default rates over the business cycle rather than at a point in time. While this makes risk assessment more complex, greater risk management efforts would already be required under the new Capital Accord and hence the marginal cost should remain limited. However, a generalised implementation of dynamic provisioning would in several countries require changes in accounting practices and taxation. ${ }^{26}$

\section{The contribution of fiscal policy to macro stability}

43. In addition to the return to low inflation, the 1990s were also characterised by a shift in fiscal policy towards the consolidation of public finances (Figure 9). From a peak of 5 per cent of GDP in 1993, the general government deficit in the OECD area was brought down to zero in 2000. Even on a cyclically-adjusted basis, the improvement in the fiscal balance was substantial, with the deficit falling from a high of over 4 per cent of GDP to less than 1 per cent in 2000. Of the countries for which data are available, only six (Japan, Germany, France, Italy, Portugal and Greece) have not seen their estimated structural balances moving into balance or surplus in the late 1990s. In most countries, consolidation resulted from both expenditure cutting and tax increases, although expenditure was the main source in Canada (Table 7). In a number of euro area countries, consolidation efforts benefited substantially from falling nominal interest rates. However, this contribution from falling nominal interest payments hides the fact that in real terms the burden of the debt may not have diminished by as much, given that the concomitant decline in inflation implies slower erosion of the real debt.

\section{[Figure 9. Fiscal balance positions and debt levels]}

\section{[Table 7. Fiscal consolidation in selected OECD countries]}

44. As a result of fiscal consolidation, the public debt-to-GDP ratio has been trending down through much of the second half of the 1990s in the vast majority of countries, with Japan standing out as a notable exception. More recently, however, deficits have returned or widened again though in most cases they remain at lower levels than a decade ago. In many cases, including countries operating fiscal rules, the worsening of the budgetary outlook has taken place in both cyclical and structural terms.

26. A compulsory system of dynamic provisioning explicitly aimed at achieving counter-cyclicality has been put in place in Spain in 2000. 


\subsection{The benefits of fiscal consolidation}

45. While in many countries fiscal consolidation required aggressive tightening, even during a period of weak economic conditions, there were also benefits. One was the crowding-in effect associated with the global decline in real interest rates. During the 1990s, real long-term interest rates have fallen significantly in most countries, and fiscal consolidation likely played a role. Several studies published in the mid-1990s found a fairly strong and significant effect using pooled data across OECD countries (See Table 2). ${ }^{27}$ This effect was corroborated by recent evidence focusing on the US experience with budget surplus forecasts during the $1990 \mathrm{~s}^{28}$

46. For countries facing adverse debt dynamics, the reduction in real interest rates helped create a virtuous circle of declining debt service burdens, lower deficits and falling sovereign risk premiums. In any case, the implied reductions in real interest rates were sufficiently broad-based to benefit most countries. In the case of euro area countries facing relatively high debt levels, an additional bonus came in the form of significant downward convergence in nominal interest rates to the levels prevailing in those countries that historically had low inflation.

47. Another potential benefit from fiscal consolidation is the support it provides to the credibility of the price stability objective pursed in most countries. There is a debate in the literature on the extent to which institutional independence granted to most OECD central banks can be undermined by fiscal policy that is seen as unsustainable. The fiscal theory of the price level suggests that unless discretionary fiscal policy can assure public debt solvency, monetary policy may not have ultimate control on the price level. Hence, in order for central banks to more fully benefit from functional independence, it has been agreed that an institutional mechanism imposing fiscal discipline may be needed.

48. The relevance of this theory has been questioned by some authors on the ground that it is based on "very peculiar conditions" 29 or that it may apply only in fairly extreme cases. Furthermore, some have argued that even mechanisms such as the Stability and Growth Pact or a balanced budget amendment are more stringent than required to address this specific issue (Canzoneri, et al., 2002). Moreover, in a context of high capital mobility, unsustainable fiscal policies would likely be sanctioned by financial markets before reaching the point of threatening the control of central banks on price determination. Even so, it cannot be excluded that agents' expectations of future inflation outcomes can be influenced by the strong political pressures on monetary policy that high-debt servicing costs usually generate.

49. A third benefit from fiscal consolidation is that it puts countries in a better position to let automatic fiscal stabilisers fully operate over the business cycles. As the experience of the 1990s has shown, high deficits and debts levels may force countries to override stabilisers and run fiscal policy in a pro-cyclical fashion. ${ }^{30}$ Automatic fiscal stabilisers clearly contribute to damp business cycles, at least in the case of demand shocks. Results from simulations based on the OECD's INTERLINK model suggest

27. Ford and Laxton (1995) found that a 1 percentage point increase in the debt ratio has led to a rise in the real interest rate of 25 basis points.

28. See Canzoneri, et al. (2002), who look at the effect of CBO surplus forecasts on interest rates and find a clear negative relationship between the interest spreads (five and ten-year Treasury notes to three-month T-bill). Regression results suggest that an increase in the deficit ratio of 1 percentage point generates an increase in the spread between long- and short-term rates of over 50 basis points.

29. Buiter (2002), for example, notes that in versions of the theory, the government's inter-temporal budget constraint does not hold, except in equilibrium.

30. Recent empirical evidence has shown that the public finance position is one key factor influencing the ability of governments to run fiscal policy in a counter-cyclical fashion (Hemming et al., 2002). 
that for most OECD countries, the variance of output gaps would have been ceteris paribus between 10 and 50 per cent higher in the 1990s without the contribution from automatic stabilisers (Table 8). ${ }^{31}$ While this in itself is significant, lower output volatility and uncertainty may in addition have a positive impact on trend GDP, either via stronger and/or better investment or the reduced risk of hysteresis effects. ${ }^{32}$ Furthermore, in contrast to discretionary policy, they are not subject to delays in decision-making and implementation, and hence can operate in a timely fashion. Accordingly, having larger stabilisers that can fully operate diminishes the need for using discretionary policy as a stabilisation tool. In this regard, the tendency for discretionary policy to be less actively used in EU countries compared with the United States may be partly explained by the fact that stabilisers in the former countries are on average about twice the size of those estimated in the latter.

\section{[Table 8. The simulated impact of fiscal policy on the cyclical volatility of GDP]}

\subsection{The experience with fiscal rules}

50. Past experience has shown that owing in part to political pressures, discretionary fiscal policy has often been conducted in a non-symmetric fashion over the cycle. While it has generally re-enforced automatic stabilisers in downturns, the tendency during the 1970s and 1980s has been to spend away eventual surpluses that would otherwise have been generated in periods of excess demand, largely contributing to the deficit bias and build-up in public debt (Figure 10) ${ }^{33}$ Even in countries (e.g. the United States) where discretionary policy has been more systematically counter-cyclical, the degree of tightening in periods of expansions has generally been lower than the extent of loosening observed during slowdowns. As a result, several countries were forced to consolidate their public finance positions during the downturn of the 1990s, contributing to its persistence.

51. Apart from the political economy considerations, the difficulty at times in distinguishing between permanent and transitory shocks to government spending and revenues, combined with the uncertainty of the growth assumptions that lie behind budgetary projections, underlines the need to run discretionary policy in a cautious manner. An example of the first uncertainty in the substantial rise in US government revenues associated with the boom in activity and share prices of the late 1990s that led to overly optimistic budget projections which again conditioned tax and spending decisions. An example of the latter is that most countries took a few years to revise down the output growth rate underlying their budgetary plans, following the marked deceleration of productivity in the mid-1970s leading to widening deficits in the late 1970s-early 1980s.

\section{[Figure 10. Output gaps and the change in the government structural balance]}

52. One way to cope with the inherent uncertainty of budget projections and remove the deficit bias is to move towards a more rule-based approach to discretionary fiscal policy. Doing so, however, raises a number of questions, including: what should be the appropriate target (the level of debt, deficit or expenditures); whether it should be satisfied at all times or only over a defined horizon (e.g. the business cycle); and whether specific items (e.g. public investment) should be excluded from the target definition.

31. See Van den Noord, 2002. A reduction in output volatility would have been around 25 per cent on average.

32. By supporting activity during downturns, stabilisers contribute to limit the extent to which hysteresis factors in the labour and/or product market may take hold.

33. This can also be characterised as not allowing automatic stabilisers to work symmetrically. See Alesina and Perotti, (1995), for an overview of political economy factors leading to the deficit bias in the conduct of discretionary policy. 
In addressing these questions, arguments based on economic efficiency are put against practical considerations.

- The rationale for targeting directly the debt level is that it is better suited to addressing considerations of long-term sustainability and inter-generational equity. However, given the difficulties involved in defining an optimal level as well as the problems created by implicit liabilities and assets, the choice is bound to be largely arbitrary, with the risk of undermining the perceived degree of commitment. Targets focussed on the level of the deficit or on expenditures have the advantage of simplicity and of being more easily understood by the wider public. On the other hand, while a deficit target can be useful during a period of fiscal consolidation, it may not provide adequate control on expenditures in times of budgetary surpluses. A drawback of both debt and deficit targets is that they can always be satisfied through higher taxes with attendant negative consequences for economic growth. This points towards an expenditure target; however, in practice, it is easy to circumvent and does not ensure that stability objections will be met.

- A deficit target specified in terms of the cyclically adjusted balance has the advantage of flexibility, allowing for automatic stabilisers to respond to cyclical fluctuations and to deal with exceptional circumstances while controlling the deficit bias. The benefit, however, comes at the cost of reduced simplicity and clarity given that the target is subject to substantial margins of interpretation. Targeting the actual balance has, in this respect, the advantage of being more credible, although the latter can be just as easily undermined by excessive use of "escape" clauses and/or creative accounting to circumvent the rule.

- Considering that public investment confers benefits to current and future generations alike, inter-generational equity considerations argue in favour of choosing a target consistent with the golden rule, i.e. that excludes capital expenditures. Such a practice has the advantage also of counteracting the bias against public investment observed in the past in several countries. In practice, however, the distinction between current and capital outlays embedded in accounting conventions is to some extent arbitrary and ignores for instance potentially important elements such as education and health. In addition, current and capital outlays are frequently linked such as in the case of expenditures to maintain the existing capital stock.

53. Several countries have changed their fiscal policy framework towards a more transparent, rule-based approach (Table 9). While the nature and strength of the rules has varied across countries, in all cases the aim has been to tighten the constraints on discretionary interventions so as to restore credibility of the policy process. In this respect, the rules should be credible; they have to be set in clear simple terms, perceived to be binding and underpinned by some form of sanctions. Those found in the former US Budget Enforcement Act, which elapsed at the end of 2002, and the Stability and Growth Pact come close to to satisfy these criteria. In both cases, they are set in terms of actual deficits or expenditures and the legislated numerical limits are underpinned with explicit pecuniary sanctions, in the form of across-the-board cuts in the United States and non-remunerated deposits in the European Union. However, given that such rules tend to lack the flexibility needed for fiscal policy to fulfil its stabilising role or to deal with special events, they typically contain "escape" clauses. In the United States, the spending caps that were imposed under the Budget Enforcement Act were accompanied by a clause allowing for "emergency appropriations". Likewise, EU countries breaching the 3 per cent of GDP deficit ceiling can avoid financial sanctions if the excessive deficit is due to exceptional circumstances, if it is temporary and if it remains close of the 
ceiling. ${ }^{34}$ Taking another approach, Canada's framework has anticipated special events by establishing a contingency reserve.

\section{[Table 9. Changes in the fiscal frameworks in the 1990s in selected OECD Member countries]}

54. Another way to alleviate the trade-off between flexibility and effectiveness is via an increase in transparency. This has been the approach taken in the United Kingdom, Australia and New Zealand. ${ }^{35}$ Even though numerical rules are set, they are not necessarily legislated and they are defined in a way that allows for a more flexible use of discretionary policy, at least over the business cycle. It is argued that despite this extra flexibility, credibility can be maintained by raising transparency of the budgetary process (Kilpatrick, 2001). In all three countries, the change was introduced after most of the consolidation effort was achieved, suggesting that such a framework may be more useful once a position of budget balance has been established. Looking at past experience, there is some empirical evidence that transparency of budget procedures has a positive impact on fiscal discipline (von Hagen and Harden, 1995), but given that this is based on results that pre-date the major consolidation effort, the conclusion should be interpreted cautiously.

55. For as long as the political momentum and popular support for fiscal consolidation was strong, rules based on numerical targets, such as those that were used in the United States until recently and the European Union, proved to be quite useful in helping countries focus on clear objectives, even though the specific contribution of the rules in restoring sound public finance can not be easily established (Hemming and Kell, 2001). This was particularly the case for several EU countries with high deficit levels and for whom participation in Stage III of EMU provided a powerful additional incentive. However, once the 3 per cent of GDP rule was satisfied -- and entry into EMU Stage III secured -- pursuing consolidation to achieve the "close-to-balance or surplus" objective proved much more difficult for the largest euro area Member States, underscoring the limits of the rules-based approach. Likewise, soon after the budget moved in to surplus position in the United States, the constraint of the spending caps was lifted through a series of emergency appropriations in 1999 and 2000 and by a lifting of the caps for 2001 and 2002, following which the rule was not renewed.

56. In the case of the euro area, while in principle the "close-to-balance or surplus" rule is designed to ensure that countries run discretionary policy symmetrically over the cycle, it has not prevented some countries (in particular the largest three Member States and Portugal) from offsetting the effect of automatic stabilisers during the upswing of the late 1990s. Not surprisingly, the subsequent economic slowdown pushed the deficit beyond the 3 per cent limit in 2002 in three countries (Germany, France and Portugal) and close to the limit in a fourth one (Italy). By early 2003 two of these (Germany and Portugal) were already under the so-called Excessive Deficit Procedure, implying that they would have to tighten fiscal policy before a recovery was well underway. The first step of such a procedure was initiated for France at the beginning of April 2003. Partly to avoid a situation where several countries feel constrained to tighten fiscal policy during a downturn, the Commission had previously delayed the requirement to have a balanced budget from 2004 to 2006. These developments confirmed the fears expressed at the outset by many that once EMU participation was locked-in, peer pressures and the threat of possible sanctions would not be sufficient to compensate for the inherent asymmetry in the Pact, created by the absence of a binding rule during upswings.

34. The exceptionality clause is automatically granted if GDP falls by over 2 per cent in the year the 3 per cent ceiling is breached. It can still be granted if GDP falls by between 0.75 and 2.0 per cent, but a formal approval by the EU Council is required in such case.

35. Their approach has contributed to the development of international codes: OECD Best Practices for Budget Transparency and the IMF Code on Good Practices on Fiscal Transparency. 
57. Responding to growing pressures for changing the Pact, the Commission has made a set of proposals to the Council in late 2002 to amend the implementation rules while preserving their main thrust. ${ }^{36}$ One of the key changes proposed would be to interpret the "close-to-balance" budget rule in cyclically-adjusted terms, implying that it should be aimed at every year. Countries deviating from the objective would commit to a pre-set time path for a return to a balanced structural budget (subsequently specified as at least a 0.5 per cent of GDP decline in the cyclically-adjusted deficit per year). ${ }^{37}$ While in principle this would have the advantage of providing fiscal rules with needed flexibility it might not be as easy to apply in practice without undermining the credibility of the Pact. In order to strengthen the peer pressure process, the Commission is also proposing to enforce the rule in ex ante rather than ex post terms so as to make the pain of non-compliance be felt much more rapidly. ${ }^{38}$ These proposals have been endorsed by the EU Council during the Spring Meeting of 20-21 March 2003.

58. Overall, the experience with the US Budget Enforcement Act and the Stability and Growth Pact illustrates that the types of rules that may be helpful during a phase of deficit reduction may no longer be sufficient after consolidation has been achieved. In this regard, it is worth noting that both Canada and Switzerland modified their rules after the initial balanced budget objective was achieved. While Canada has shifted emphasis from deficit to debt reduction, Switzerland has adopted an expenditure rule that essentially aims at keeping the budget balanced over the cycle. ${ }^{39}$

\subsection{Fiscal sustainability in the longer term}

59. The extent to which the new frameworks will ensure better fiscal discipline in the future and prevent another build-up of high debt levels remains to be seen, especially considering the twin pressures to lower tax burdens and to fund rising health care and pension costs. In addition to short- and medium-term considerations, fiscal policy should thus be assessed from a long-term perspective, taking into account not just the existing government liabilities but also explicit and implicit tax and spending commitments. Of particular interest are the budgetary consequences of policies designed to address major issues such as demographic changes. However, solvency considerations can also have immediate repercussions, as it is sometimes dramatically illustrated by the sovereign spreads on developing countries' debt.

60. Conceptually, sustainability of fiscal policies is usually seen in terms of the inter-temporal government constraint, which states that today's stock of debt should be matched by the discounted value of the future stream of primary surpluses (Blanchard, et al., 1990). Due to its infinite horizon dimension, no single arithmetic rules on the budget or the debt level result directly from this approach. ${ }^{40}$ On the other hand, consistency assessments of fiscal policies are made over a finite time horizon. For this reason, the

36. See the Communication from the Commission to Council and the European Parliament on Strengthening the co-ordination of budgetary policies issued in November 2002 (http://europa.eu.int/eur-lex/en/com/cnc/2002/com2002_0668en01.pdf).

37. See conclusions from the $2493^{\text {rd }}$ Council meeting on Economic and Financial Affairs held in Brussels on 7 March 2003 (http://ue.eu.int/pressData/en/ecofin/74844.pdf). Small temporary structural deficits would be accepted for countries with a low debt ratio.

38. Under the current rule, it may take several years before the sanctions attached to an Excessive Deficit Procedure are actually imposed.

39. Following a referendum in Spring 2002, this rule has been placed in the constitution and will be effective starting with the 2003 federal budget.

40. In fact, the required transversality condition simply imposes that the debt does not grow faster than the interest rate. 
practical definition of sustainability in these exercises requires the specification of some constraints in addition to the general implications of the inter-temporal budget constraint. One common approach is to assume that the debt-to-GDP ratio at the end of the process returns to its starting level. The sustainability of a given fiscal programme can then be measured by the fiscal gap, the immediate and permanent change in the primary balance needed to satisfy that debt rule (Auerbach, 1994). ${ }^{41}$

61. Some work has been done looking at the practical implementations of the inter-temporal budget constraint approach for the discussion of fiscal sustainability of some OECD economies.

- Under current policies, New Zealand will be facing some serious fiscal imbalances in fifty years time. Given current projections for demographic and related health care developments, the current primary balance surpluses will turn negative at around 2020, resulting in a fiscal gap of about 1.57 per cent of GDP by 2051. Consequently, the enforcement of a 30 per cent target for the debt-to-GDP ratio in that terminal year ${ }^{42}$ would require a tightening of the fiscal policy over the entire projection horizon (Janssen, 2002).

- Kennedy and Matier (2002) compare the long-term fiscal outlook for Canada and the United States presenting a homogenous treatment of pension plans in both countries. In this context, despite the apparent high level of federal debt in Canada relative to that in the United States, current Canadian fiscal policies were assessed as being sustainable in the long run. In contrast, current fiscal policy in the United States will eventually lead to tax hikes and/or cuts in spending. According to the authors' projections, even assuming that the recently enacted tax cuts expire in 2010, the US fiscal gap (the amount of fiscal tightening required to satisfy the debt rule) will emerge after 2050 and will reach 1.0 per cent of GDP by 2075 .

- Federiksen (2001) discusses fiscal sustainability in 19 OECD economies using a different implementation of the budget constraint approach, which in contrast to the other two studies does not require the imposition of an end-point -- or finite horizon -- constraint. ${ }^{43}$ The author concludes that from a long-term perspective the fiscal consolidation of the last few years still requires significant tightening for all but a small group of countries. Based on these scenarios, EU member countries would need to enact a further permanent tax increase or spending cut of the order of 2.5 per cent of GDP. As in the Kennedy and Matier paper, current US fiscal policies are judged to be unsustainable, with a required permanent adjustment of 2.2 per cent of GDP. In contrast with that paper, however, the Danish submission concludes that Canadian fiscal policies will also have to be tightened over the long term (2.9 per cent of GDP).

62. However, it should be recognised that the assessment of long-term fiscal sustainability is fraught with difficulties. In the first place, the practical implementation of the concept of sustainability itself generally requires the reduction of the inter-temporal budget constraint to finite time implications. The resulting conditions are neither necessary nor sufficient for sustainability. Furthermore, given the extended horizons of these exercises, the assumptions adopted for the path of key economic variables such as potential growth and real interest rates may well reveal themselves as poor approximations to the actual outcomes. Finally, most simulations are conducted in partial equilibrium fashion, ignoring important feedback effects.

41. A similar concept, the tax gap, is due to Blanchard, et al. (1990).

42. This is the debt-to-GDP ratio in the initial projection period.

43. The paper computes an index of fiscal sustainability, which is equal to the adjustment of the primary surplus required to prevent further, future changes in fiscal policy. For computational ease, an exponential adjustment path is used. 
63. In addition, the measurement of sustainability tends to ignore the fact that even fiscal scenarios that are sustainable on an accounting basis could nonetheless be unsustainable politically. ${ }^{44}$ For instance, they could imply pensions at poverty levels or they might imply an unsustainable shift of the burden from the current to future generations (such as could be the case when a country decides to go from a pay-as-you-go to a fully-funded system).

44. For example, Fredereiksen's (2001) assessment of sustainability of fiscal policies in Italy and the United Kingdom holds true largely due to the fact that these are the only two countries for which pensions do not penalise primary balances in the long run (Table 1). However, the paper relies on the OECD ageing projections (Dang et al., 2001), which foresee Italy and the United Kingdom as the only two countries where the relative weight of pension spending in GDP will decline in the next fifty years. Interestingly, Dang et al., (2001) also show that these two countries hold two of the most extreme positions among OECD countries regarding the weight of pension spending in GDP. In 2000, at 14.2 per cent of GDP Italy had the highest pension spending of all OECD countries. In contrast, pension spending in the United Kingdom amounted to just 4.3 per cent of GDP. 


\section{BIBLIOGRAPHY}

AHEARNE, A., J. GAGNON, J. HALTMAIER and S. KAMIN; C. ERCEG, J. FAUST, L. GUERRIERI, C. HEMPHILL, L. KOLE, J. ROUSH, J. ROGERS, N. SHEETS and J. WRIGHT (2002), "Preventing deflation: Lessons from Japan's experience in the 1990s", International Finance Discussion Papers, No. 729, Board of Governors of the Federal Reserve System.

AKERLOF, G.A., W.T. DICKENS and W.L. PERRY (1996),

"The macroeconomics of low inflation", Brookings Papers on Economic Activity 1.

AKERLOF, G.A., W.T. DICKENS and W.L. PERRY (2000),

"Near rational wage and price setting and the long run Phillips curve", Brookings Papers on Economic Activity 1.

ALCHIAN, A. and B. KLEIN (1973),

"On a correct measure of inflation", Journal of Money, Credit and Banking, Vol. 5, No. 1, Part 1.

ALESINA, A. and R. PEROTTI (1995),

"The political economy of budget deficits", IMF Staff Papers, Vol. 42, No. 1.

ALTONJI, J.G. and P.J. DEVEREUX (1999),

"The extent and consequences of downward and nominal wage rigidity", NBER Working Paper Series, No. 7236.

ANDERSEN, P.S. and W.L. WASCHER (1999),

"Sacrifice ratios and the conduct of monetary policy in conditions of low inflation", BIS Working Papers, No. 82.

AUERBACH, A.J. (1994),

"The US fiscal problem: Where we are, how we got here and where we're going", NBER Working Paper Series, No. 4709.

BAKHSHI, H., A.G. HALDANE, and N. HATCH (1999),

"Quantifying some benefits of price stability", in The Costs and Benefits of Price Stability, M. Feldstein (ed.).

BALL, L., N.G. MANKIW and D. ROMER (1988),

"The new Keynesian economics and the output inflation trade-off", Brookings Papers on Economic Activity 1.

BALL, L. (1994),

"What determines the sacrifice ratio?", in Monetary Policy, G. Mankiw (ed.), University of Chicago Press. 
BALL, L. (1997),

"Disinflation and the NAIRU", in Reducing Inflation: Motivation and Strategy, C. Romer and

D. Romer (eds), University of Chicago Press.

BASSANINI, A., S. SCARPETTA and P. HEMMINGS (2001),

"Economic growth: The role of policies and institutions. Panel data evidence from OECD

countries", OECD Economics Department Working Papers, No. 283.

BEISSINGER, T. and C. KNOPPIK (2000),

"Downward nominal rigidity in West-German earnings 1975-1995", University of Regensburg

Discussion Paper, No. 344.

BERNANKE, B.S. (2002),

"Asset-price 'bubbles' and monetary policy", remarks before the New York Chapter of the National Association for Business Economics, Board of Governors of the Federal Reserve System, October.

BEWLEY, T.F. (1999),

Why Wages Don't Fall During a Recession, Cambridge and London: Harvard University Press.

BLANCHARD, O. and L. SUMMERS (1986),

"Hysteresis and the European unemployment problem", NBER Macroeconomics Annual, No. 1.

BLANCHARD, O., J.-C. CHOURAQUI, R.P. HAGEMANN and N. SARTOR (1990),

"The sustainability of fiscal policy: New answers to an old question", OECD Economic Studies, No. 15, Paris.

BONATO, L. (1998),

"Price stability: some costs and benefits in New Zealand", Reserve Bank of New Zealand Discussion Paper Series, No. G98/10, November.

BORIO, C. and P. LOWE (2002),

"Asset prices, financial and monetary stability: exploring the nexus", BIS Working Papers, No. 114.

BOUDOUKH, J., M. RICHARDSON and R.F. WHITELAW (1994),

"Industry returns and the Fisher effect", Journal of Finance, Vol. 49, No. 5, December.

BRAYTON, F., J. ROBERTS and J. WILLIAMS (1999),

"What's happened to the Phillips Curve?", manuscript, Division of Research and Statistics, Board of Governors of the Federal Reserve System, Washington.

BRIAULT, C., A. HALDANE and M. KING (1996),

"Independence and accountability", Bank of England Working Papers, No. 49.

BUITER, W.H. (2002),

"The fiscal theory of the price level: A critique", Royal Economic Society, USA, The Economic Journal, Vol. 112, July.

BUITER, W.H. and C. GRAFE (2002),

"Anchor, float or abandon ship: Exchange rate regimes for the accession countries", European Bank for Reconstruction and Development, London. 
CANZONERI, M.B., R.E. CUMBY and B.T. DIBA (2002),

"Should the European Central Bank and the Federal Reserve be concerned about fiscal policy". Paper prepared for the Federal Reserve Bank of Kansas City's symposium on Rethinking Stabilization Policy, at Jackson Hole, 29 August.

CARD, D. and D. HYSLOP (1997),

"Does inflation grease the wheels of the labor market", Reducing Inflation, NBER Studies in

Business Cycles, Vol. 30, C.D. Romer and D.H. Romer (eds), University of Chicago Press.

CECCHETTI, S.G., H. GENBERG, J. LIPSKY and S. WADHWANI (2000),

"Asset prices and central bank policy", report prepared for the International Centre for Monetary and Banking Studies Conference on Central Banks and Asset Prices, The Geneva Report on the World Economy, No. 2.

CHRISTIANO, L.J. (2000),

"Comment on theoretical analysis regarding a zero lower bound on nominal interest rates", Journal of Money, Credit and Banking, Vol. 32, No. 4, Part 2, November.

CORICELLI, F. and JAZBEC, B. (2001),

"Real exchange rate dynamics in transition economies", CEPR Discussion Paper Series, No. 2869, July.

CRAWFORD, A. (2001),

"How rigid are nominal-wage rates?", Bank of Canada Working Paper, No. 8.

CUNNINGHAM, A. and A.E. HALDANE (1999),

"The monetary transmission mechanism in the United Kingdom: Pass-through and policy rules", Bank of England.

DALSGAARD, T., J. ELMESKOV and C.-Y. PARK (2002),

"Ongoing changes in the business cycle -- evidence and causes", OECD Economics Department Working Papers, No. 315.

DANG, T.T., P. ANTOLIN and H. OXLEY (2001),

"Fiscal implications of ageing: Projections of age-related spending", OECD Economics Department Working Papers, No. 305.

DOLADO, J.J., J.M. GONZÁLEZ-PÁRAMO and J. VIÑALS (1999),

"A cost-benefit analysis of going from low inflation to price stability in Spain", in The Costs and

Benefits of Price Stability, M. Feldstein (ed.).

ECB (2001),

"The new capital adequacy regime - the ECB perspective", ECB Monthly Bulletin, May.

EDEY, M. and K. HVIDING (1995),

"An assessment of financial reform in OECD countries", OECD Economics Department Working Papers, No. 154.

ÉRCEG, B. (2002),

"Investigating the Balassa-Samuelson hypothesis in the transition: Do we understand what we see? A panel study", The European Bank for Reconstruction and Development, Economics of Transition, Vol. 10 (2). 
FEHR, E. and L. GOETTE (2000),

"Robustness and real consequences of nominal wage rigidity", Institute for Empirical Research in Economics, University of Zurich Working Paper, No. 44.

FELDSTEIN, M. (1980),

"Inflation and the stock market", American Economic Review, Vol. 70, No. 5, December.

FELDSTEIN, M. (1997),

"The costs and benefits of going from low inflation to price stability", in Reducing Inflation:

Motivation and Strategy, C.D. Romer and D.H. Romer (eds.).

FELDSTEIN, M. (1999),

"Capital income taxes and the benefit of price stability", in The Costs and Benefits of Price Stability, M. Feldstein (ed.).

FISCHER, S. (1999),

Comment on "Capital income taxes and the benefit of price stability" by M. Feldstein, in The Costs and Benefits of Price Stability, M. Feldstein (ed.).

FORD, R. and D. LAXTON (1995),

"World public debt and real interest rates", IMF Working Paper, No. 95/30, Washington.

FORTIN, P. (1996),

"The great Canadian slump", Canadian Journal of Economics, Vol. 29, Issue 4.

FREDERIKSEN, N.K (2001),

"Fiscal Sustainability in the OECD", Ministry of Finance Working Paper, No. 3/2001, Ministry of

Finance, Denmark.

FREEDMAN, C. (2001),

"The value of transparency in conducting monetary policy", Remarks prepared for a panel discussion at the $26^{\text {th }}$ annual economy policy conference of the Federal Reserve Bank of St. Louis, Getting the Markets in Synch with Monetary Policy, 11-12 October.

FUHRER, J. (2001),

Comment on "Monetary policy issues in a low inflation environment" by J. Viñals in Why Price Stability? A. García Herrero, V. Gaspar, L. Hoogduin, J. Morgan, B. Winkler (eds), ECB, Frankfurt, June.

GOODHART, C.A.E. and B. HOFMANN (2000),

"Do asset prices help predict consumer price inflation?", unpublished manuscript, Financial Markets Group, London School of Economics.

GREENSPAN, A. (2002),

"Economic volatility", speech at a symposium sponsored by the Federal Reserve Bank of Kansas

City, Jackson Hole, Wyoming, August.

GROSHEN, E.L. and M.E. SCWEITZER (1997),

"Identifying inflation's grease and sand effects in the labour market", NBER Working Paper Series, No. 6061. 
HEMMING, R. and M. KELL (2001),

"Promoting fiscal responsibility: Transparency, rules and independent fiscal authorities", paper presented at Bank of Italy workshop on Fiscal Rules, Perugia, February.

HEMMING, R., S. MAHFOUZ and A. SCHIMMELPFENNIG (2002),

"Fiscal policy and economic activity during recessions in advanced economies", IMF Working Paper, No. 02/87, Washington.

HOLDEN, H. (2002),

"The costs of price stability -- downward nominal wage rigidity in Europe", NBER Working Paper Series, No. 8865 .

HOWITT, P. (2002),

"Looking inside the labor market: A review article", Journal of Economic Literature, Vol. 40, No. 1, March.

JANSSEN, J. (2002),

"Long-term fiscal projections and their relationship with the inter-temporal budget constraint: An application to New Zealand", New Zealand Treasury Working Paper, No. 02/04.

KAHN, S. (1997),

"Evidence of nominal wage stickiness from micro-data", American Economic Review, Vol. 87, No. 5, December.

KENNEDY, M., A. PALERM, C. PIGOTT and F. TERRIBILE (1998),

“Asset prices and monetary policy", OECD Economics Department Working Papers, No. 188.

KENNEDY S. and C. MATIER (2002),

"Comparing the long-term fiscal outlook for Canada and the United States using fiscal gaps," Department of Finance Working Paper, Canada, forthcoming.

KILPATRICK, A. (2001),

"Transparent frameworks, fiscal rules and policy making under uncertainty", paper presented at Bank of Italy workshop on Fiscal Rules, Perugia, February.

KIMURA, T. and K. UEDA, (1997),

"Downward nominal wage rigidity in Japan: Is price stability costly?", Bank of Japan Research and Statistics Department Working Paper Series, No. 97-1.

KING, M. (1999),

Challenges for Monetary Policy: New and Old. Proceedings of a Symposium on New Challenges for Monetary Policy, sponsored by the Federal Reserve Bank of Kansas City, Jackson Hole, Wyoming, 26-28 August.

KNOPPIK, C. and T. BEISSINGER (2001),

"How rigid are nominal wages? Evidence and implications for Germany", IZA Discussion Paper, No. 357, University of Regensburg.

KOVÁCS, M.A. (2002 (ed.)

"On the estimated size of the Balassa-Samuelson effect in five Central and Eastern European countries", National Bank of Hungary Working Paper No. 5, July. 
KRUGMAN, P. (1998),

"It's baaaack! Japan's slump and the return of the liquidity trap", Brookings Papers on Economic Activity 2.

KUTTNER, K. and A. POSEN (2001),

Beyond Bipolar: A Three-Dimensional Assessment of Monetary Frameworks, Institute for International Economics and the Federal Reserve Bank of New York.

LAXTON, D. and P. N'DIAYE (2002),

"Monetary policy credibility and the unemployment-inflation tradeoff: Some evidence from seventeen OECD countries", IMF Working Paper, No. 02/220, Washington.

LEBOW, D.E., D.J. STOCKTON and W.L. WASCHER (1995),

"Inflation, nominal wage rigidity, and the efficiency of labor markets", Finance and Economics Discussion Series 94-95, , Division of Monetary Affairs, Board of Governors of the Federal Reserve System.

LOWE, P. (2002),

"Credit risk measurement and procyclicality", BIS Working Papers, No. 116.

McCALLUM, B.T. (2000),

"Theoretical analysis regarding a zero lower bound on nominal interest rates", Journal of Money,

Credit and Banking, Vol. 32, No. 4, Part 2.

McLAUGHLIN, K.J. (1994),

"Rigid wages?", Journal of Monetary Economics, No. 34, Issue 3, December.

McLAUGHLIN, K.J. (1999),

"Are nominal wage changes skewed away from wage cuts?", unpublished paper, Hunter College

CUNY.

MELTZER, A. (2000),

"Monetary policy in the new global economy: The case of Japan", The Cato Journal, Vol. 20, No. 1.

MODIGLIANI, F. and R.A. COHN (1979),

"Inflation and the stock market", Financial Analyst Journal, No. 35.

NORDHAUS, W.D. (2002),

"The mildest recession: Output, profits, and stock prices as the U.S. emerges from the 2001

recession", NBER Working Paper Series, No. 8938.

OECD (1998),

Economic Outlook, No. 64, Paris.

OECD (2000),

Economic Outlook, No. 67, Paris.

OECD (2001),

OECD Economic Surveys, Japan, Paris.

OECD (2002),

Economic Outlook, No. 71, Paris. 
O'REILLY, B. and M. LEVAC (2000),

"Inflation and the tax system in Canada: An exploratory partial-equilibrium analysis", Bank of Canada Working Paper, No. 18.

ORR, A., M. EDEY and M. KENNEDY (1995),

"Real long-term interest rates: the evidence from pooled time series", OECD Economic Studies, No. 25.

PELGRIN, F., S. SCHICH and A. DE SERRES (2002),

"Increases in business investment rates in OECD countries in the 1990s: How much can be explained by fundamentals?", OECD Economics Department Working Papers, No. 327.

PERSAUD, A. (2000),

"Sending the herd off the cliff edge: The disturbing interaction between herding and market-sensitive risk management practices", State Street, September.

PERSSON, M., T. PERSSON and L.E.O. SVENSSON (1996),

"Debt, cash flow and inflation incentives: A Swedish example", NBER Working Paper Series, No. 5772.

PIGOTT, C. and H. CHRISTIANSEN (1998),

"Monetary policy when inflation is low", OECD Economics Department Working Papers, No. 191.

PIVETTA, F. and R. REIS (2002),

"The persistence of inflation in the United States", Harvard University.

POSEN, A. (2002),

Six Practical Views of Central Bank Transparency, Institute for International Economics.

RICHARDSON, P., L. BOONE, C. GIORNO, M. MEACCI, D. RAE and D. TURNER (2000),

"The concept, policy use and measurement of structural unemployment: estimating a time varying NAIRU across 21 OECD countries", OECD Economics Department Working Papers, No. 250.

SCHICH, S. and F. SEITZ (1999),

Changing the Institutional Design of Central Banks, University of Applied Sciences, Amberg-Weiden and OECD Economics Department, Paris.

SHARPE, S.A. (2002),

"Re-examining stock valuation and inflation: The implications of analysts' earnings forecasts", The Review of Economics and Statistics, Vol. 84, No. 4, November.

SHILLER, R.J. (1997),

"Why do people dislike inflation", Reducing Inflation, NBER Studies in Business Cycles, Vol. 30,

University of Chicago Press.

SINN, H.-W. and M. REUTTER (2001),

"The minimum inflation rate for euroland", NBER Working Paper Series, No. 8085.

SMITH, J.C. (2000),

"Nominal wage rigidity in the United Kingdom", The Economic Journal, No. 110. 
STAIGER, D., J.H. STOCK and M.W. WATSON (2001),

"Prices, wages and the U.S. NAIRU in the 1990s", paper prepared for the conference on the

Sustainable Employment Initiative, sponsored by the Century and Russell Sage Foundations.

SUMMERS, L.H. (1991),

"How should monetary policy be determined?", Journal of Money, Credit and Banking, Vol. 23, No. 3, Part 2, August.

SVENSSON, L.E.O. (2001),

"The zero-bound in an open economy: A foolproof way of escaping from a liquidity trap", Bank of Japan Monetary and Economic Studies, No. 19.

TAYLOR, J.B. (2000),

"Low inflation, pass-through, and the pricing power of firms", European Economic Review, Vol. 44, No. 7, June.

TÖDTER, K.-H. and G. ZIEBARTH (1999),

"Price stability vs. low inflation in Germany: An analysis of costs and benefits", The Costs and Benefits of Price Stability, M. Feldstein (ed.).

VIÑALS, J. (2001),

"Monetary policy issues in a low inflation environment", Why Price Stability? A. García Herrero, V. Gaspar, L. Hoogduin, J. Morgan, B. Winkler (eds), ECB, Frankfurt.

VON HAGEN, J. and I.J. HARDEN (1995),

"Budget processes and commitment to fiscal discipline", European Economic Review, Vol. 39, Issue 3-4, April.

WADHWANI, S.B. (2000),

"Monetary challenges in a new economy", Bank of England Quarterly Bulletin, Vol. 40, No. 4.

WADHWANI, S.B. (2002),

"The MPC: Some further challenges", speech delivered at the National Institute of Economic and Social Research Governor's Seminar, London. 


\section{Table 1. Estimated impact of inflation changes on output per capita ${ }^{a}$}

\begin{tabular}{|c|c|c|c|c|}
\hline \multirow[b]{2}{*}{ Variable } & \multicolumn{3}{|c|}{$\begin{array}{l}\text { Impact on output per working age } \\
\text { person } \\
{\text { (per cent })^{b}}^{\text {per }}\end{array}$} & \multirow{2}{*}{$\begin{array}{l}\text { Order of } \\
\text { magnitude } \\
\text { with respect } \\
\text { to OECD } \\
\text { experience } \\
(1980 \text { s-90s })^{c}\end{array}$} \\
\hline & $\begin{array}{l}\text { Effect via } \\
\text { economic } \\
\text { efficiency }\end{array}$ & $\begin{array}{l}\text { Effect via } \\
\text { investment }\end{array}$ & $\begin{array}{l}\text { Overall } \\
\text { effect }\end{array}$ & \\
\hline $\begin{array}{l}\text { Inflation rate } \\
\text { (fall of } 1 \% \text { point) }\end{array}$ & & 0.4 to 0.5 & 0.4 to 0.5 & $\begin{array}{l}\text { about } 1 / 4 \text { the } \\
\text { observed fall }\end{array}$ \\
\hline $\begin{array}{l}\text { Variability of inflation } \\
\text { ( } 1 \% \text { point fall in the standard deviation of inflation) }\end{array}$ & 2.0 & & 2.0 & $\begin{array}{l}\text { about } 1.5 \text { times } \\
\text { the observed fall }\end{array}$ \\
\hline $\begin{array}{l}\text { Tax burden } \\
\text { (increase of } 1 \% \text { point) }\end{array}$ & -0.3 & -0.3 to -0.4 & -0.6 to -0.7 & $\begin{array}{l}\text { about } 2 / 3 \text { of the } \\
\text { observed increase }\end{array}$ \\
\hline $\begin{array}{l}\text { a) The values reported in this table are the estimated long- } \\
\text { The range reported reflects the values obtained in differ } \\
\text { b) The effect via economic efficiency (direct effect) refers } \\
\text { on the accumulation of physical capital. The effect via i } \\
\text { on the investment rate and by that channel, on output } p \\
\text { c) Average change from the } 1980 \text { average to the } 1990 \text { ave } \\
\text { excluding new Members as well as Iceland, Luxembour } \\
\text { d) In percentage of GDP. }\end{array}$ & $\begin{array}{l}\text { In effects on o } \\
\text { it specification } \\
\text { the impact on } \\
\text { estment (indir } \\
\text { capita. } \\
\text { ge in the sam } \\
\text { and Turkey. }\end{array}$ & $\begin{array}{l}\text { tput per workir } \\
\text { s of the growth } \\
\text { output per capi } \\
\text { ect effect) refers } \\
\text { le of } 21 \text { OECD }\end{array}$ & $\begin{array}{l}\text { g-age person o } \\
\text { equation. } \\
\text { a over and abo } \\
\text { to the combine } \\
\text { countries, }\end{array}$ & $\begin{array}{l}\text { aiven policy change. } \\
\text { any potential influence } \\
\text { impact of the variable }\end{array}$ \\
\hline
\end{tabular}

\section{Table 2. Real long-term interest rate equation}

\section{7 country simultaneous estimation}

Dependent variable: first difference of real long-term interest rates

Quarterly data from 1981 Q2 to 1994 Q2

\begin{tabular}{|c|c|c|c|}
\hline Variable & ECM coefficient & t-statistic & $\begin{array}{l}\text { Implied long-run } \\
\text { coefficient }\end{array}$ \\
\hline & \multicolumn{3}{|c|}{ Constrained coefficients } \\
\hline Error correction & -0.079 & -8.42 & \\
\hline Return on capital & 0.019 & 5.06 & 0.24 \\
\hline Risk & 0.122 & 4.44 & 1.54 \\
\hline Past minus expected inflation & 0.027 & 3.31 & 0.34 \\
\hline Current account & -0.012 & -2.31 & -0.15 \\
\hline Government deficit & 0.012 & 2.32 & 0.15 \\
\hline
\end{tabular}

Note: For data sources and definitions see the Annex to Orr et al., 1995. 
ECO/WKP(2003)7

Table 3. Estimated costs and benefits of reducing inflation by two percentage points

Summary of findings in the literature

\begin{tabular}{llcc}
\hline \multicolumn{1}{c}{ Country } & \multicolumn{1}{c}{ Authors } & $\begin{array}{c}\text { Permanent gain in } \\
\text { GDP }\end{array}$ & $\begin{array}{c}\text { Temporary disinflation } \\
\text { costs (Ball, 1994) }\end{array}$ \\
\hline Canada & O'Reilly and Levac (2000) & 0.11 to 1.08 & 2.40 \\
Germany & Tödter and Ziebarth (1999) & 2.04 & 5.04 \\
New Zealand & Bonato (1998) & 0.28 to 0.39 & 1.06 \\
Spain & Dolado, Gonzalez-Paramo, and Viñals (1999) & & 1.80 \\
Sweden & Persson, Persson and Svensson (1996) & $0.72^{b}$ & 0.90 \\
United Kingdom & Bakhshi, Haldane and Hatch (1999) & 0.41 to 0.52 & 1.36 \\
United States & Feldstein (1997, 1999) & 0.85 to 1.14 & 4.60 \\
\hline
\end{tabular}

a) Average sacrifice ratio, annual data.

b) Indirect welfare costs - possible compensatory tax increases - not included. 


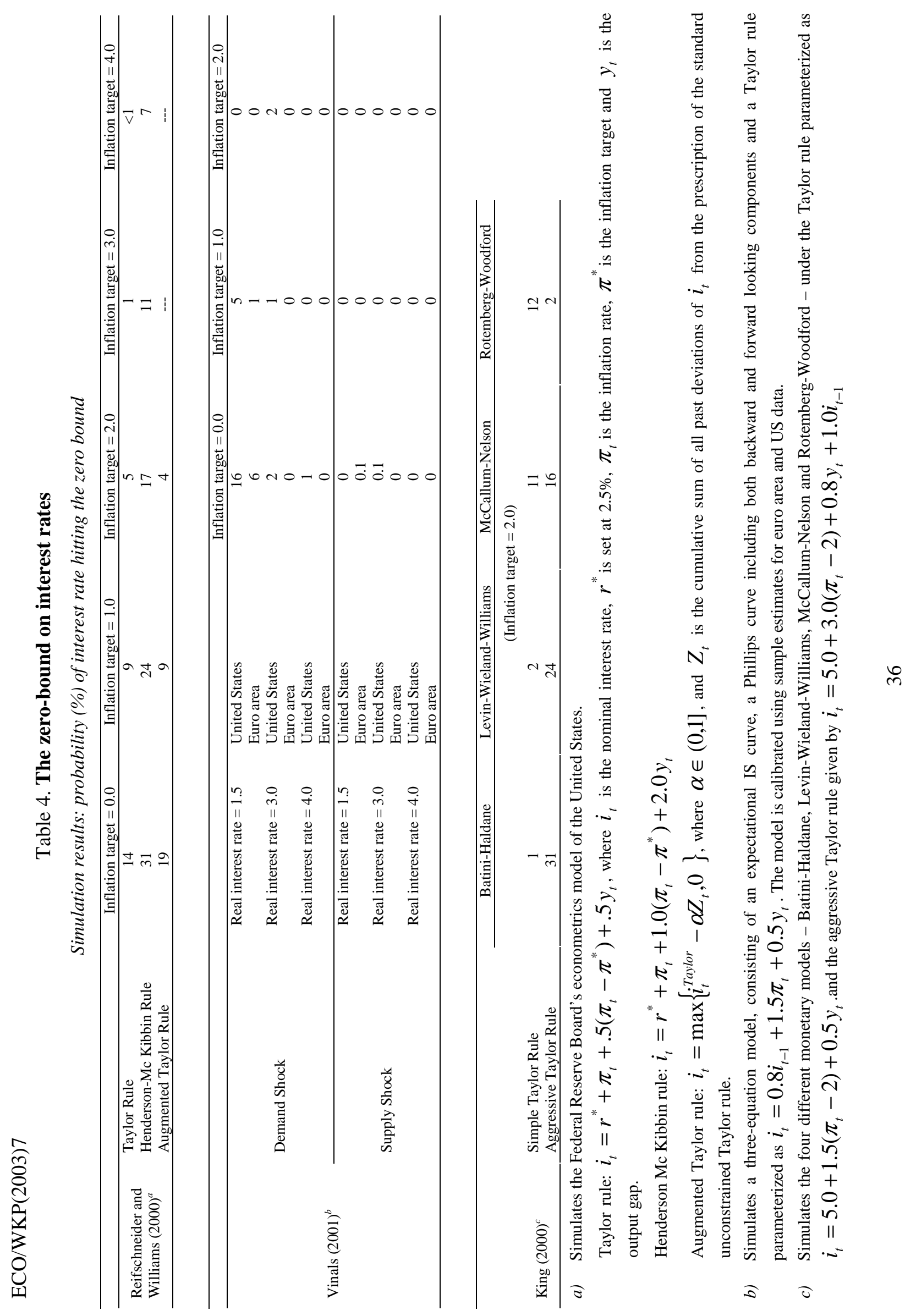




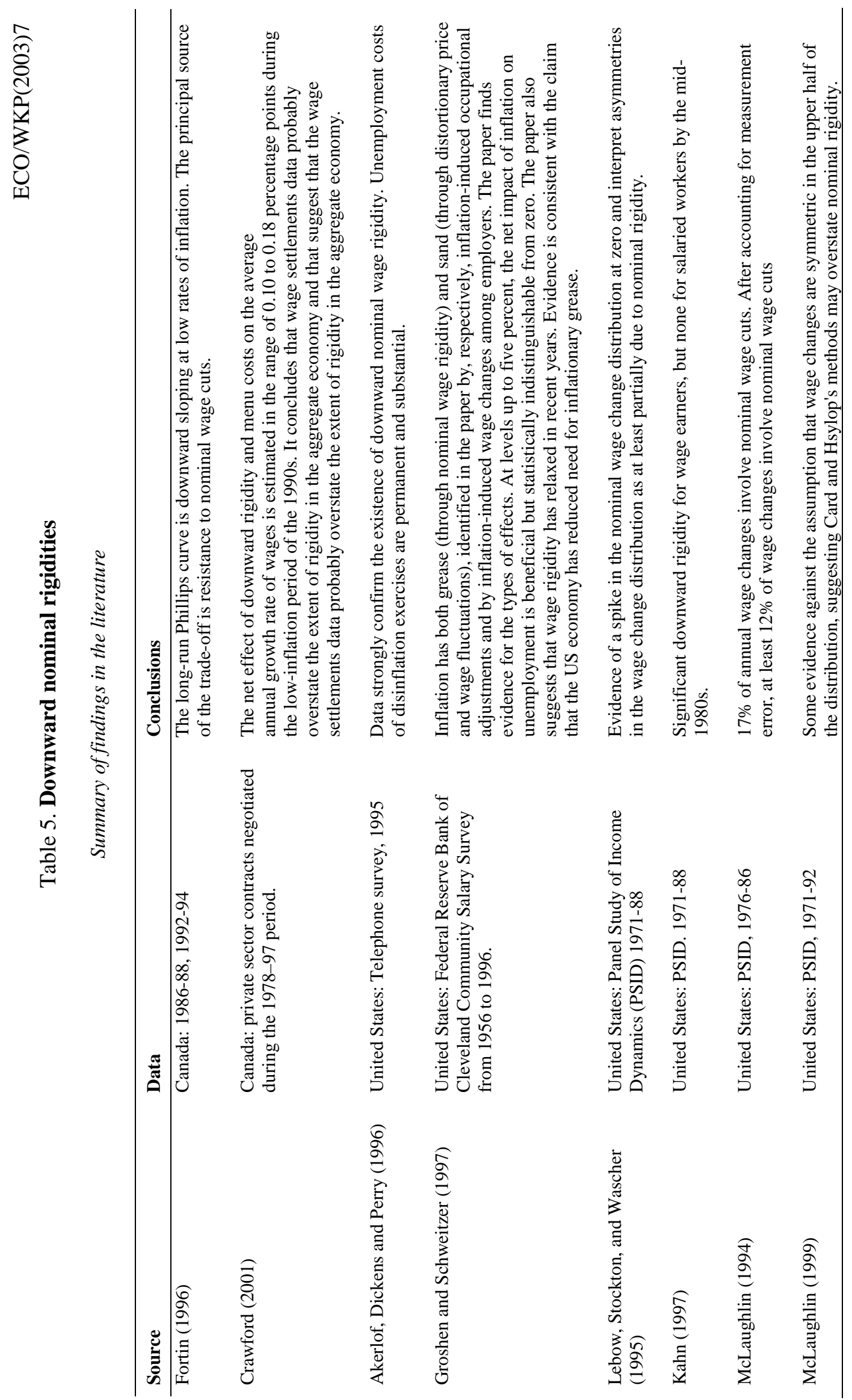




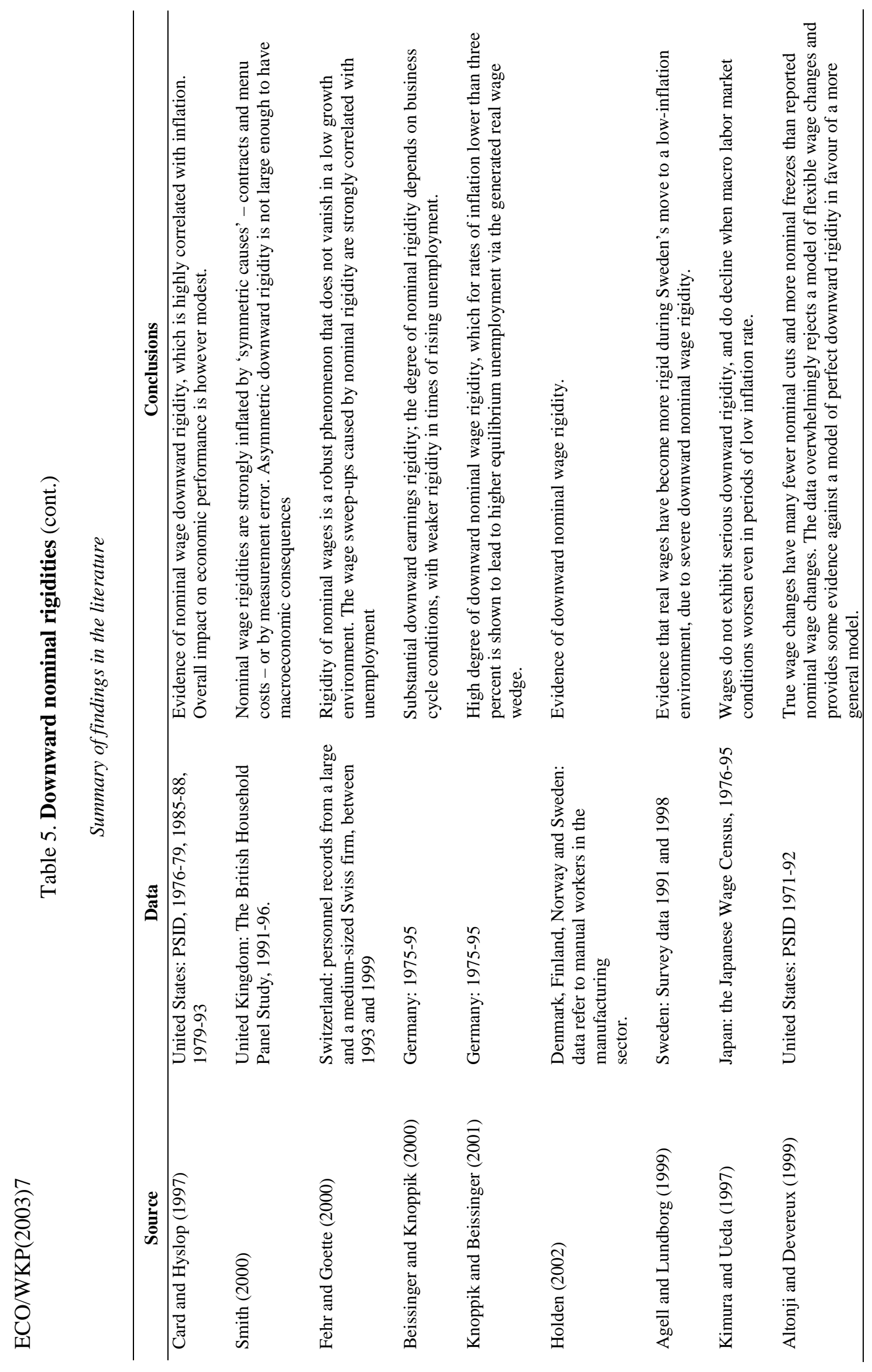


ECO/WKP(2003)7

\section{Table 6. Recent changes of institutional structures of central banks in selected OECD Member countries}

\begin{tabular}{|c|c|c|}
\hline Country & Year & Summary of changes $^{a}$ \\
\hline Australia & 1997 & $\begin{array}{l}\text { (t) The Commonwealth Authorities and Companies Act requires the Reserve Bank Board to } \\
\text { prepare an annual report, for presentation to the Treasurer and tabling in Parliament (usually } \\
\text { in late August or early September). }\end{array}$ \\
\hline Czech Republic & 1998 & $\begin{array}{l}\text { (o) Currency stability as explicit objective; } \\
\text { (i) Instrumental and operational independence of the Czech National Bank (CNB) guaranteed by } \\
\text { the Constitution; } \\
\text { (i) The decision making related to monetary policy delegated to the CNB Board, in which } \\
\text { government representatives have no vote; } \\
\text { (i) Board members cannot be dismissed on account of disagreements with government in } \\
\text { monetary policy; } \\
\text { (t) Minutes and records of the CNB Board meetings are publicly disclosed; } \\
\text { (t) Every six months the Bank must report on its activities to Parliament. } \\
\text { (o) Formal inflation target; } \\
\text { (t) Publication of quarterly Inflation Reports. } \\
\text { (o) Price stability as explicit objective. }\end{array}$ \\
\hline Euro area & 1998 & $\begin{array}{l}\text { (o) In accordance with the Treaty establishing the European Community and the Statute of the } \\
\text { European System of Central Banks and of the European Central Bank (ECB), the primary } \\
\text { objective of the Eurosystem, which is composed of the ECB and the National Central Banks } \\
\text { (NCBs) of the euro area, is to maintain price stability; } \\
\text { (i) The Eurosystem is independent - when performing Eurosystem-related tasks, neither the } \\
\text { ECB, nor an NCB, nor any member of their decision-making bodies may seek or take } \\
\text { instructions from any external body; } \\
\text { (i) The Community institutions and bodies and the governments of the Member States may not } \\
\text { seek to influence the members of the decision-making bodies of the ECB or of the NCBs in } \\
\text { the performance of their tasks; } \\
\text { (i) The Statute makes provision for the following measures to ensure security of tenure for NCB } \\
\text { governors and members of the Executive Board: i) a minimum renewable term of office for } \\
\text { governors of five years; ii) a minimum non-renewable term of office for members of the } \\
\text { Executive Board of eight years (it should be noted that a system of staggered appointments } \\
\text { was used for the first Executive Board for members other than the President in order to } \\
\text { ensure continuity); and iii) removal from office is only possible in the event of incapacity or } \\
\text { serious misconduct; in this respect the Court of Justice of the European Communities is } \\
\text { competent to settle any disputes. }\end{array}$ \\
\hline Hungary & 2001 & $\begin{array}{l}\text { (o) Price stability as primary objective; } \\
\text { (o) Formal inflation target set for end } 2001 \text {, end } 2002 \text { and end 2003; } \\
\text { (i) Independence of the Central Bank in formulating and implementing monetary policy; } \\
\text { (t) Monthly reports of the Central Bank and quarterly reports on inflation of the monetary } \\
\text { council present detailed accounts of monetary policy, inflation forecasts and risks; } \\
\text { (t) Every year the Bank reports its activities to the Parliament. }\end{array}$ \\
\hline
\end{tabular}




\section{Table 6. Recent changes of institutional structures of central banks in selected OECD Member countries (cont.)}

\begin{tabular}{|c|c|c|}
\hline Country & Year & Summary of changes ${ }^{a}$ \\
\hline Japan & 1998 & $\begin{array}{l}\text { (o) Price stability as explicit objective; } \\
\text { (i) Independence of the Bank of Japan in formulating and implementing monetary policy; } \\
\text { (i) Assigns the decision making concerning monetary policy to a single body -- the Policy } \\
\text { Board -- in which government representatives have no vote; government influence on choice } \\
\text { of Policy Board members reduced; } \\
\text { (i) Board members cannot be dismissed in cases of conflict with government; } \\
\text { (t) Minutes and records of the Policy Board meetings will be publicly disclosed; } \\
\text { (t) Every six months the Bank must report on its activities to the Diet. }\end{array}$ \\
\hline Korea & 1998 & $\begin{array}{l}\text { (o) Price stability as primary objective; } \\
\text { (i) Governor of the Bank of Korea serves as the Chairman of the Monetary Policy Committee, } \\
\text { replacing the Minister of Finance and Economy; } \\
\text { (i) The Monetary Policy Committee is reduced from nine to seven, with only one nominated by } \\
\text { the government; } \\
\text { (i) Committee Members serve on a full-time basis and cannot be dismissed on the grounds of a } \\
\text { conflict with the government; } \\
\text { (t) Minutes of the Monetary Policy Committee meetings will be publicly disclosed with a delay } \\
\text { of three months; } \\
\text { (t) Every year the Bank must report on its activities to the National Assembly on semi-annual } \\
\text { basis. }\end{array}$ \\
\hline Mexico & $\begin{array}{l}1995 \\
1999 \\
2000\end{array}$ & $\begin{array}{l}\text { (o) Price stability as primary objective; } \\
\text { (i) Board members are appointed by the President and ratified by the Senate (six years for the } \\
\text { governor and eight years for the four deputy governors); } \\
\text { (i) Independence of the Banco de México (Banxico) in formulating and implementing monetary } \\
\text { policy. } \\
\text { (t) Banxico announces annual inflation target and the time path of monetary base (intermediate } \\
\text { target). } \\
\text { (o) Bringing down inflation to } 3 \text { per cent as long-term objective in line with that of the trading } \\
\text { partners. } \\
\text { (t) Inflation reports published quarterly. }\end{array}$ \\
\hline New Zealand & $\begin{array}{l}1996 \\
2000 \\
2002\end{array}$ & $\begin{array}{l}\text { (o) Inflation target range widened to } 0-3 \text { per cent. } \\
\text { (i) The Chairman of the Board of Directors becomes a non-executive director, rather than the } \\
\text { Governor. } \\
\text { (t) Inflation target becomes } 1-3 \text { per cent on average over the medium term. }\end{array}$ \\
\hline Poland & $\begin{array}{l}1999 \\
2000\end{array}$ & $\begin{array}{l}\text { (o) Price stability as basic objective. Insofar as this does not preclude the pursuit of basic } \\
\text { objective, National Bank of Poland (NBP) acts in support of Government policies; } \\
\text { (i) Independence of NBP in its instruments - since 1989; } \\
\text { (i) Decision making related to monetary policy delegated to the Monetary Policy Council; } \\
\text { (i) Council's Members -- of which there are nine plus the governor -- appointed in equal } \\
\text { numbers by the President of the Republic, the lower house of Parliament (Sejm) and the } \\
\text { Senate; } \\
\text { (i) Council members recalled only for reasons of resignation, illness, criminal offence, adhesion } \\
\text { to a political party or a trade union; } \\
\text { (t) Council draws up annual monetary policy guidelines and submits them to Sejm; } \\
\text { (t) Council presents a report on the performance of monetary policy guidelines within } \\
\text { (o) Formal adoption of an inflation target. } \\
\text { (o) Adoption of a floating exchange rate regime. }\end{array}$ \\
\hline
\end{tabular}


ECO/WKP(2003)7

\section{Table 6. Recent changes of institutional structures of central banks in selected OECD Member countries (cont.)}

\begin{tabular}{|c|c|c|}
\hline Country & Year & Summary of changes ${ }^{a}$ \\
\hline Slovak Republic & 2001 & $\begin{array}{l}\text { (o) Price stability as the principal mandate, in place of currency stability, which is now the } \\
\text { second objective; } \\
\text { (i) The National Bank of Slovakia (NBS) is made fully independent; } \\
\text { (i) The Bank is prohibited from providing monetary financing of the public deficit. }\end{array}$ \\
\hline Sweden & 1993 & $\begin{array}{l}\text { (t) Formal inflation target is specified by the Riksbank; } \\
\text { (t) Inflation report. } \\
\text { (o) Explicitly lays down price stability as objective of monetary policy; } \\
\text { (o) Responsibility for exchange rate regime (only) transferred to government; } \\
\text { (i) Previous Governing Board (appointed by the Parliament) is replaced by an Executive Board } \\
\text { of six members, each elected for a period of six years } \\
\text { (i) The Riksbank no longer required to consult but only to inform government on important } \\
\text { monetary policy decisions; }\end{array}$ \\
\hline Switzerland & 2000 & $\begin{array}{l}\text { (o) Price stability on the medium term as objective to avoid both inflation and deflation; } \\
\text { (t) The Swiss National Bank publishes forecasts of inflation over the three-year horizon twice a } \\
\text { year as well as quarterly assessment of monetary policy; } \\
\text { (t) Publication of various models on which projections are based. }\end{array}$ \\
\hline Turkey & 2000 & $\begin{array}{l}\text { (i) Responsibility of banking supervision transferred to Banking Regulation and Supervisory } \\
\text { Agency. } \\
\text { (o) Price stability as explicit objective; } \\
\text { (i) Decision making related to monetary policy delegated to Monetary Policy Committee (MPC) } \\
\text {-- the members are Governor, Vice Governors, one member to be elected from the Board and } \\
\text { one member to be designated by Council of Ministers upon the proposal of the Governor -- in } \\
\text { which a representative of the Treasury can attend but has no vote; } \\
\text { (t) Any form of direct lending from the Central Bank to the Treasury is forbidden. } \\
\text { (t) Inflation target set explicitly; } \\
\text { (t) Publication of independent assessment of inflation. }\end{array}$ \\
\hline United Kingdom & $\begin{array}{l}1992 \\
1993 \\
1994 \\
1997\end{array}$ & $\begin{array}{l}\text { (t) Inflation target by Chancellor of the Exchequer and Bank of England (BoE); } \\
\text { (i,t) The BoE produces independent assessment of progress in meeting inflation target. } \\
\text { (i) The BoE is given discretion over timing of changes in interest rates. } \\
\text { (i,t) Publication of the minutes of the meetings between the BoE and the Chancellor in which the } \\
\text { former gives its independent advice to the latter. } \\
\text { (i) The BoE is given authority over the setting of interest rates; } \\
\text { (i) Policy decisions are made by a new Monetary Policy Committee (MPC), the members of } \\
\text { which will be appointed by the Governor and the Chancellor. A representative of the } \\
\text { (i) Greasury will attend the meetings of the MPC, but has no vote; } \\
\text { (o) Responsibility for banking supervision will be transferred to a separate institution; } \\
\text { (o) Responsibility for debt management transferred to the Treasury. }\end{array}$ \\
\hline
\end{tabular}

a) Changes affecting the objectives, the degree of independence and transparency are identified (o), (i) and (t) respectively.

Source: OECD. 
Table 7. Fiscal consolidations in selected OECD countries

Changes in general government, in per cent of $G D P^{a}$

\begin{tabular}{|c|c|c|c|c|c|c|}
\hline & $\begin{array}{c}\text { Net } \\
\text { lending }\end{array}$ & $\begin{array}{c}\text { Cyclically- } \\
\text { adjusted } \\
\text { net lending }\end{array}$ & $\begin{array}{c}\text { Cyclically- } \\
\text { adjusted } \\
\text { revenues }\end{array}$ & $\begin{array}{c}\text { Cyclically- } \\
\text { adjusted } \\
\text { expenditures }\end{array}$ & $\begin{array}{c}\text { Net } \\
\text { interest } \\
\text { payments }\end{array}$ & $\begin{array}{r}\text { Gross } \\
\text { debt }\end{array}$ \\
\hline \multicolumn{7}{|l|}{ Major economies } \\
\hline United States (1993-2000) & 7.3 & 6.2 & 3.0 & -1.9 & -1.0 & -14.6 \\
\hline United Kingdom (1994-2000) & 11.9 & 6.9 & 3.1 & -2.0 & -0.2 & -6.6 \\
\hline Canada (1993-2000) & 12.2 & 9.4 & 0.2 & -6.9 & -1.9 & -7.6 \\
\hline Euro area (1994-2000) & 5.9 & 3.2 & 0.5 & -0.6 & -1.6 & 4.1 \\
\hline \multicolumn{7}{|l|}{ Euro area countries } \\
\hline Austria (1996-2001) & 5.3 & 5.1 & 3.0 & -1.4 & -1.2 & -6.0 \\
\hline Belgium (1993-2001) & 8.5 & 8.8 & 2.8 & -1.0 & -4.6 & -24.2 \\
\hline Finland (1994-2000) & 14.4 & 4.6 & -0.9 & -3.9 & 1.4 & -5.4 \\
\hline France (1994-2000) & 4.6 & 3.3 & 2.1 & -0.6 & -0.1 & 13.8 \\
\hline Germany (1997-2000) & 4.5 & 1.0 & 0.5 & -0.3 & -0.3 & 0.2 \\
\hline Greece (1994-2001) & 12.4 & 10.0 & 7.2 & 4.0 & -6.3 & -3.2 \\
\hline Ireland (1996-2000) & 6.7 & 3.8 & -1.3 & -4.0 & -3.0 & -43.6 \\
\hline Italy (1991-2000) & 11.2 & 10.8 & 3.0 & -1.6 & -3.9 & 13.2 \\
\hline Netherlands (1995-2000) & 6.4 & 4.7 & 0.3 & -4.3 & -1.1 & -19.9 \\
\hline Portugal (1994-2000) & 3.0 & 1.0 & 0.4 & 3.9 & -2.8 & -6.0 \\
\hline Spain (1996-2001) & 6.5 & 4.7 & 1.7 & -0.4 & -2.0 & -5.4 \\
\hline \multicolumn{7}{|l|}{ Other OECD } \\
\hline Australia (1993-99) & 7.1 & 5.4 & 4.5 & 0.6 & -1.4 & -0.5 \\
\hline Denmark (1994-99) & 6.0 & 2.7 & 0.5 & 0.1 & -1.2 & -28.9 \\
\hline Iceland (1995-2000) & 7.2 & 4.3 & 6.2 & 4.0 & -0.6 & -14.2 \\
\hline New Zealand (1991-94) & 7.7 & 5.8 & -1.2 & -2.3 & -2.9 & .. \\
\hline Norway (1994-97) & 9.9 & 7.2 & 1.7 & -4.0 & 1.0 & -12.6 \\
\hline Sweden (1994-98) & 14.0 & 10.6 & 2.2 & -4.5 & 1.8 & 2.6 \\
\hline Total OECD (1994-2000) & 5.1 & 3.3 & 1.1 & .. & -1.0 & 1.9 \\
\hline
\end{tabular}

Note: Fiscal consolidation are defined between 1990 and 2001 as periods of protracted (more than three years) improvements in the annual general government's net lending position in per cent of GDP, as compared to the previous year, where such periods are allowed to be interrupted if the worsening of that balance does not exceed 0.5 per cent of GDP and does not last for more than one year.

a) Value in the last year of the consolidation minus the value in the year before the consolidation.

b) Excluding interest payments.

Source: OECD. 
ECO/WKP(2003)7

Table 8. The simulated impact of fiscal policy on the cyclical volatility of GDP

Root mean square of output gap, 1991-1999

\begin{tabular}{|c|c|c|c|}
\hline \multirow[b]{3}{*}{ Finland } & \multirow[b]{2}{*}{ Actual $^{b}$} & \multicolumn{2}{|c|}{ Increase $(+)$ or decrease(-) attributable to: } \\
\hline & & Automatic stabilisers & Discretionary policy \\
\hline & 5.7 & -7.8 & -2.9 \\
\hline Ireland & 3.6 & -0.4 & -0.7 \\
\hline Sweden & 2.9 & -1.0 & -1.1 \\
\hline New Zealand & 2.8 & -0.9 & -0.4 \\
\hline Canada & 2.7 & -0.7 & 0.8 \\
\hline Japan & 2.6 & -0.4 & -2.3 \\
\hline Italy & 2.3 & -0.7 & 1.7 \\
\hline Spain & 1.9 & -0.4 & -1.1 \\
\hline Belgium & 1.8 & -0.5 & 0.7 \\
\hline France & 1.8 & -0.3 & 0.1 \\
\hline Greece & 1.8 & -0.3 & -2.6 \\
\hline Australia & 1.7 & -0.3 & -1.7 \\
\hline United Kingdom & 1.6 & -0.7 & -0.4 \\
\hline United States & 1.6 & -0.3 & -2.4 \\
\hline Germany & 1.4 & -0.8 & -0.3 \\
\hline Austria & 1.3 & -0.1 & -1.4 \\
\hline Netherlands & 1.1 & -0.4 & -1.5 \\
\hline Average of above & 2.3 & -0.9 & -0.9 \\
\hline
\end{tabular}

a) The formula for the root mean square of the output gap reads: $\sqrt{\frac{1}{9}} \sum_{t=1-1991}^{2000} \operatorname{gap}_{t}^{2}$

where: $\operatorname{gap}=\left(y-y^{*}\right) / y^{*} ; y=G D P$ and $y^{*}=$ potential GDP.

b) Countries are ranked according to cyclical variability of the output gap.

Source: Van den Noord (2002). 
ECO/WKP(2003)7

Table 9. Changes in fiscal frameworks since the $1990 \mathrm{~s}$

\begin{tabular}{|c|c|c|}
\hline Country/region & Year & Summary of changes \\
\hline Australia & 1998 & $\begin{array}{l}\text { Charter for Budget Honesty } \\
\text { Rule } \\
\text { - No legislated numerical rules. The Charter requires the government to spell out objectives and } \\
\text { targets but places no constraints on their nature. } \\
\text { Enforcement/Sanctions } \\
\text { Transparency } \\
\text { - Requires the Government to prepare an annual fiscal strategy statement outlining long-term } \\
\text { fiscal policy objectives and fiscal targets for the following three years. External auditors assess } \\
\text { the statement and performance. }\end{array}$ \\
\hline
\end{tabular}

\begin{tabular}{ll}
\hline Austria & $2000 \quad \begin{array}{l}\text { Domestic Stability Pact } \\
\text { Rule }\end{array}$
\end{tabular}

- Negotiated floors on the budget balance for each government level (0.75 per cent of GDP for the Länder zero for municipalities and the federal government balance should be such that the Stability Programme target is met). The floors apply on average, over several years.

Enforcement/Sanctions

- Possible fines (8 per cent of the floor plus 15 per cent of the shortfall, up to a ceiling), subject to a unanimous decision from all interest parties.

Escape Clause

- In case of a serious economic slowdown for example, the sanction do not apply.

\begin{tabular}{|c|c|c|}
\hline \multirow[t]{2}{*}{ Belgium } & $\begin{array}{l}1996 \text { to } \\
1999\end{array}$ & Intergovernmental treaties \\
\hline & $\begin{array}{l}1999 \text { to } \\
2002\end{array}$ & $\begin{array}{l}\text { Rule } \\
\text { - Permissible deficits are established for the federal government plus the Social Security on the } \\
\text { one hand, and for the regions and the local governments on the other. } \\
\text { Enforcement / Sanctions } \\
\text { Transparency } \\
\text { - The borrowing capacity of regions and communications may be restricted. } \\
\text { Permissible deficits for the different government levels and for Social Security are established } \\
\text { which are published in annual reports. }\end{array}$ \\
\hline \multirow[t]{2}{*}{ Canada } & $\begin{array}{l}1991 \text { to } \\
1996\end{array}$ & $\begin{array}{l}\text { Federal Spending Control Act } \\
\text { Rules } \\
\text { - Limits on all programme spending except self-financing programmes. } \\
\text { - Overspending in one year permitted if offset in following two years. } \\
\text { Enforcement / Sanctions } \\
\text { - No explicit sanctions. Compliance with the Act was assessed by Auditor General. }\end{array}$ \\
\hline & 1998 & $\begin{array}{l}\text { Debt Repayment Plan } \\
\text { Rules } \\
\text { - There are no legislated rules at the federal level but the government has a "balanced budget or } \\
\text { - better" policy. } \\
\text { Most provinces have some form of balance budget legislation, with sanction that may include } \\
\text { - } \quad \text { A Contary cuts for cabinet members or forced elections. } \\
\text { may be devoted to debt reduction if not needed. }\end{array}$ \\
\hline
\end{tabular}


ECO/WKP(2003)7

Table 9. Changes in the fiscal frameworks since the 1990s (continued)

\begin{tabular}{|c|c|c|}
\hline Country/region & Year & Summary of changes \\
\hline $\begin{array}{l}\text { Euro area/ EU } \\
\text { countries }\end{array}$ & 1992 & $\begin{array}{l}\text { Maastricht Treaty; extended in } 1997 \text { under the Stability and Growth Pact } \\
\text { Rules } \\
\text { - } 3 \text { per cent of GDP ceiling on general government net borrowing. } \\
\text { - } 60 \text { per cent of gross government debt-to-GDP ratio norm. } \\
\text { - Close to balance or surplus target. } \\
\text { Enforcement / Sanctions } \\
\text { - Non-remunerated deposits with a fixed component equal to } 0.2 \text { per cent of deficit and a } \\
\text { variable component rising with size of excessive deficit. } \\
\text { Financial sanction applies only in case of non-respect of deficit rule, although peer pressures } \\
\text { can be exerted in the form of policy recommendations on the basis of the Commission's } \\
\text { assessment. } \\
\text { Escape clause } \\
\text { - Exceptional circumstances including if output falls by over } 2 \text { per cent during the year the } \\
\text { deficit exceeds the limit. } \\
\text { Transparency } \\
\text { Member States are required to report twice a year to the Commission their planned and actual } \\
\text { deficits and their debt levels. Once a year they must also submit a stability (euro area "ins") or } \\
\text { convergence ("outs") programme, which is subject to an opinion from the Council. }\end{array}$ \\
\hline Germany & 2002 & $\begin{array}{l}\text { Domestic Stability Pact } \\
\text { Rules } \\
\text { - Golden rule: the budgeted deficit of the federal government must not exceed federal } \\
\text { investment spending (by constitutional law; most Länder constitutions have a similar law). } \\
\text { - Both the government and the states (including the communities) should aim at balanced } \\
\text { budgets. } \\
\text { Enforcement / Sanctions } \\
\text { - No explicit sanctions. } \\
\text { Transparency } \\
\text { - The inter-governmental Financial Planing Council should make recommendations on how to } \\
\text { achieve fiscal discipline and monitor whether authorities' spending and the budget evolve in } \\
\text { line with the requirements of the EU Stability and Growth Pact. It can also make } \\
\text { recommendations on how to restore fiscal discipline. }\end{array}$ \\
\hline \multirow[t]{2}{*}{ Japan } & $\begin{array}{l}1997 \text { to } \\
1998\end{array}$ & $\begin{array}{l}\text { Fiscal Structural Reform Act } \\
\text { Rules } \\
\text { - Reduce fiscal deficits to } 3 \text { per cent of GDP by FY } 2003 . \\
\text { - Terminate issuance of special deficit-financing bonds by FY } 2003 . \\
\text { - Set numerical reduction targets for major expenditure areas over the subsequent three years. } \\
\text { Enforcement Sanctions } \\
\text { - No explicit sanctions. } \\
\text { Escape clause } \\
\text { - Added in } 1998 \text { in response to the economic slowdown. }\end{array}$ \\
\hline & 2002 & $\begin{array}{l}\text { Cabinet Decision on the Medium-Term Fiscal Perspective } \\
\text { Rules } \\
\text { - Maintain the size of government (measured by total general outlays as a share of GDP) at or } \\
\text { below the current level until FY } 2006 \text {. } \\
\text { Enforcement/Sanctions } \\
\text { - No explicit sanctions. }\end{array}$ \\
\hline
\end{tabular}


ECO/WKP(2003)7

Table 9. Changes in the fiscal frameworks since the 1990s (continued)

\begin{tabular}{|c|c|c|}
\hline Country/region & Year & Summary of changes \\
\hline Netherlands & 1994 & $\begin{array}{l}\text { Multi-year expenditure agreements } \\
\text { Rules } \\
\text { - Use deliberately cautious growth projections. } \\
\text { - Ceilings on central government, social security and health care spending. } \\
\text { - If the balance exceeds }-3 / 4 \text { per cent of GDP, half of the revenue windfalls can go to tax cuts. }\end{array}$ \\
\hline New Zealand & 1994 & $\begin{array}{l}\text { Fiscal Responsibility Act } \\
\text { Rule } \\
\text { - Maintain debt and net worth at "prudent" levels and run operating surpluses on average over a } \\
\text { "reasonable" period of time. The government of the day sets its own numerical targets } \\
\text { consistent with these principles. } \\
\text { Enforcement / Sanctions } \\
\text { - Given that the numerical targets are not legislated, no sanctions are specified. } \\
\text { Transparency } \\
\text { - The Act requires the Government to strengthen reporting requirements so as to provide } \\
\text { parliamentary assessments of fiscal policy, to spell out clearly the objectives and consequences } \\
\text { of policy choices and to take an aggregate and medium-term perspective. }\end{array}$ \\
\hline Norway & 2001 & $\begin{array}{l}\text { Fiscal Stability Guidelines } \\
\text { Rules } \\
\text { - Structural non-oil central-government budget deficit should equal to } 4 \text { per cent of the } \\
\text { Government Petroleum Fund over the cycle. Discretionary easing or tightening during the cycle } \\
\text { is allowed. } \\
\text { - In the event of non-compliance due to extraordinary circumstances (major re-evaluations of the } \\
\text { Fund's capital or statistical revisions of the structural deficit), corrective action should be } \\
\text { spread over several years. } \\
\text { Enforcement / Sanctions } \\
\text { No sanctions. } \\
\text { Transparency } \\
\text { Budget documentation reports the structural fiscal balances including and excluding oil } \\
\text { revenues. This is complemented with an annual update of long-term projections. }\end{array}$ \\
\hline Poland & 1999 & $\begin{array}{l}\text { Act on Public Finance } \\
\text { Rule } \\
\text { - The constitution sets a limit of } 60 \text { per cent of GDP for total public debt. } \\
\text { Enforcement /Sanctions } \\
\text { - Constraints are put on deficits, both at the national and the sub-national level, once public debt } \\
\text { exceeds } 50 \text { per cent of GDP. }\end{array}$ \\
\hline \multirow[t]{2}{*}{ Spain } & 2003 & $\begin{array}{l}\text { Fiscal Stability Law } \\
\text { Rules } \\
\text { - Accounts should balance or show a surplus at all levels of government (central, social, } \\
\text { territorial and local) as well as for public enterprises and corporations. } \\
\text { - A cap will be put on expenditure and a contingency fund ( } 2 \text { per cent of expenditure) will be set } \\
\text { up to cover unscheduled expenditure. }\end{array}$ \\
\hline & 2003 & $\begin{array}{l}\text { Escape clauses } \\
\text { - Possibility of running deficits restricted to temporary and exceptional situations. Two-to- three- } \\
\text { year plans to restore the accounts to balance will have to be discussed in Parliament. }\end{array}$ \\
\hline
\end{tabular}


ECO/WKP(2003)7

Table 9. Changes in the fiscal frameworks since the 1990s (continued)

\begin{tabular}{|c|c|c|}
\hline Country/region & Year & Summary of changes \\
\hline Sweden & 1996 & $\begin{array}{l}\text { Fiscal budget Act } \\
\text { Rules } \\
\text { - Set nominal expenditure limits for the subsequent three years on } 27 \text { expenditure areas } \\
\text { (including social security). } \\
\text { - Maintain general government surplus of } 2 \text { per cent of GDP on average over the business cycle. } \\
\text { Enforcement / Sanctions } \\
\text { - No explicit sanctions. }\end{array}$ \\
\hline \multirow[t]{2}{*}{ Switzerland } & 1998 & $\begin{array}{l}\text { Budget Objective } 2001 \\
\text { Rules } \\
\text { - Capped the federal deficit at } 2 \text { per cent of revenues or } 0.25 \text { per cent of GDP by } 2001 . \\
\text { Enforcement / Sanctions } \\
-\quad \text { Expenditure excess to be financed by tax increase. }\end{array}$ \\
\hline & 2001 & $\begin{array}{l}\text { Debt Containment Rule } \\
\text { Rules } \\
\text { - Sets a ceiling for expenditures which is equal to total revenues adjusted for the cycle and for ex } \\
\text { post deviations of out-turns from the norm laid out in the rule. } \\
\text { Enforcement / Sanctions } \\
\text { - No explicit sanctions, though deviations from the rule must be corrected within three years. } \\
\text { Escape clauses } \\
\text { - Exceptional circumstances require an absolute majority in both houses of Parliament. }\end{array}$ \\
\hline $\begin{array}{l}\text { United } \\
\text { Kingdom }\end{array}$ & 1997 & $\begin{array}{l}\text { Code for Fiscal Stability } \\
\text { Rules } \\
\text { - Golden rule: over the business cycle the Government will borrow only to invest and not to } \\
\text { fund current spending. } \\
\text { - Sustainable investment rule: net debt as a proportion of GDP must be held stable over the } \\
\text { business cycle at a prudent level defined so far as net debt below } 40 \text { per cent of GDP. } \\
\text { Enforcement / Sanctions } \\
\text { - No explicit sanctions. } \\
\text { Transparency } \\
\text { - Annual reporting cycle, including a Pre-Budget Report, an Economic and Fiscal Strategy } \\
\text { Report and a Debt Management Report. }\end{array}$ \\
\hline United States & $\begin{array}{l}1990 \text { to } \\
2002\end{array}$ & $\begin{array}{l}\text { Budget Enforcement Act } \\
\text { Rules } \\
\text { - Medium-term nominal caps for discretionary spending. } \\
\text { - Legislated changes to revenues or mandatory spending programmes should be budget neutral } \\
\text { over a five-year horizon. } \\
\text { Enforcement / Sanctions } \\
\text { - Sequestration procedures (cuts across-the-board). } \\
\text { Escape clause } \\
\text { - "Emergency appropriations" can be passed. }\end{array}$ \\
\hline
\end{tabular}


Figure 1 . Inflation, oil prices, output gaps and inflation variability
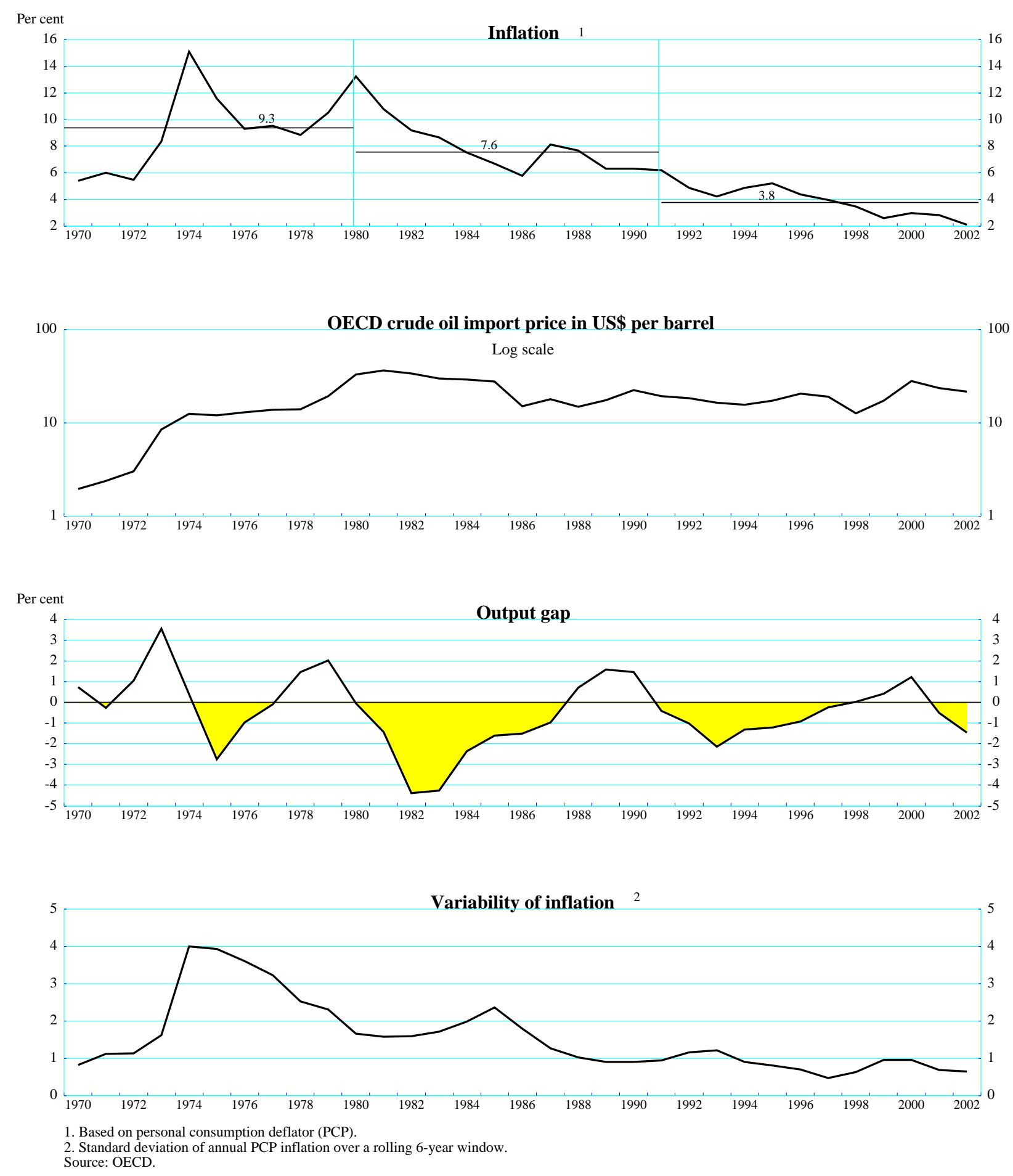
Figure 2. Real long-term interest rates in major areas

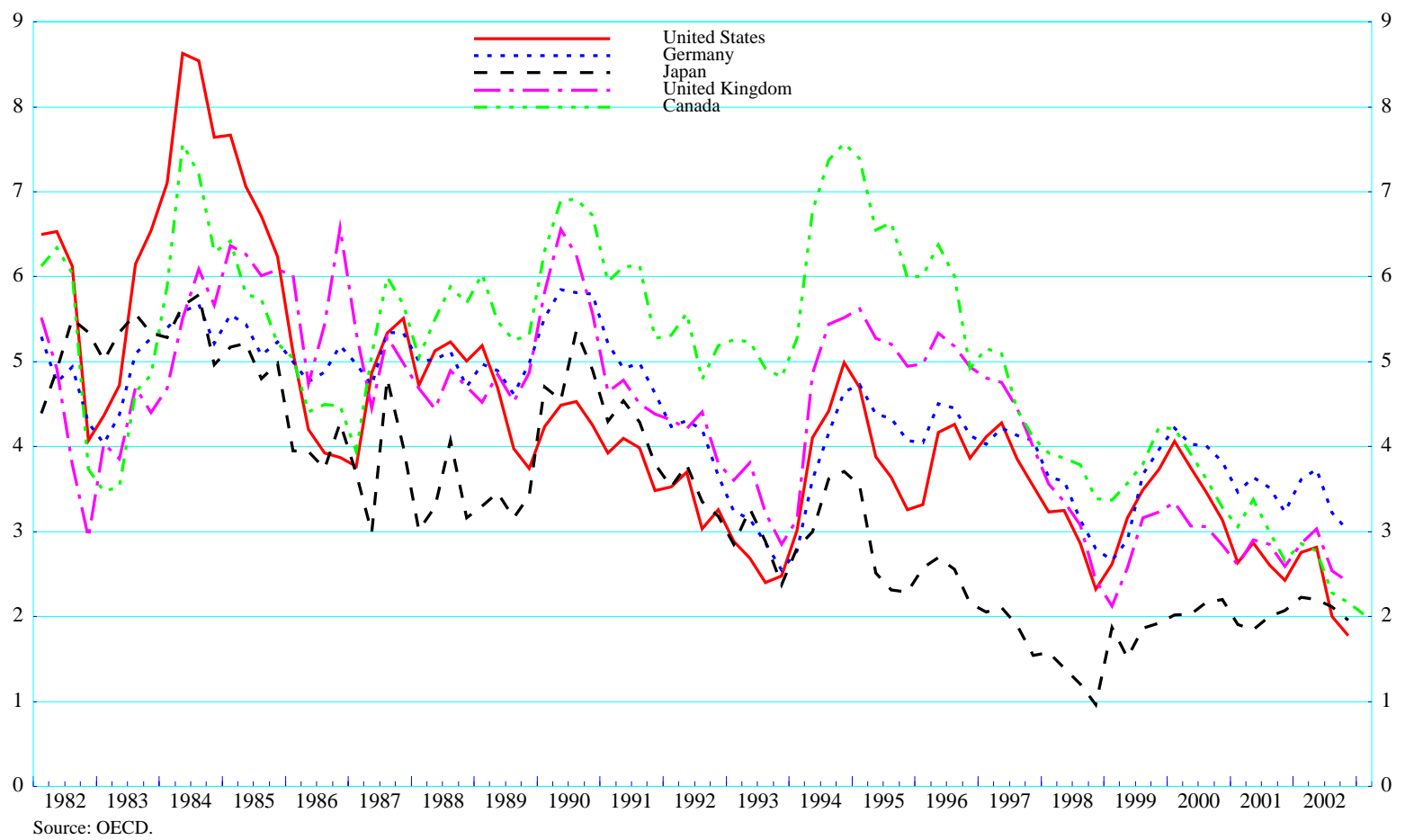


Figure 3. Implied equity premium and trend inflation
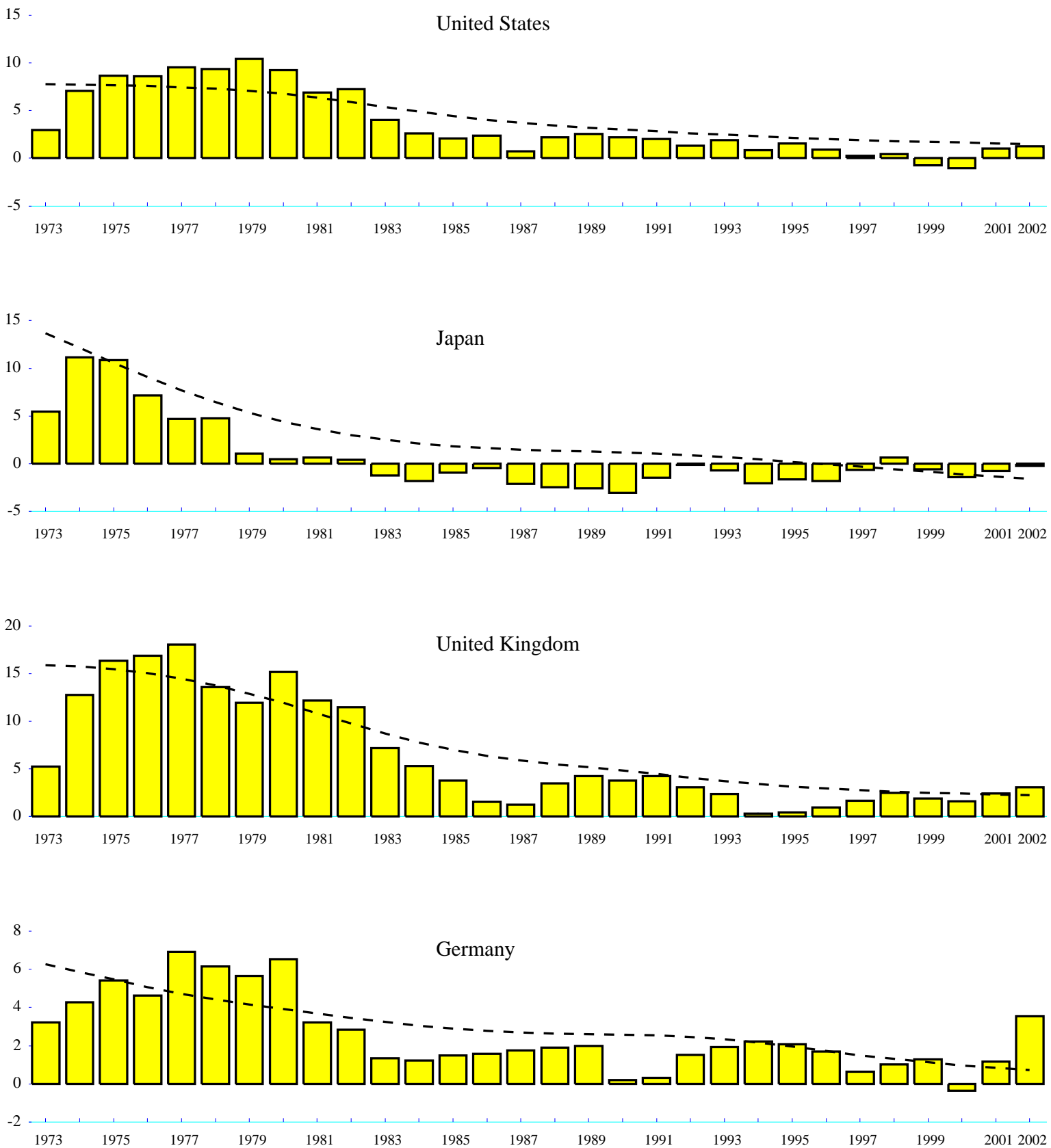

1. Annual change in the implicit GDP deflator smoothed by a Hodrick-Prescott filter. Source : OECD. 
Figure 4. Inflation volatility versus output volatility (1)
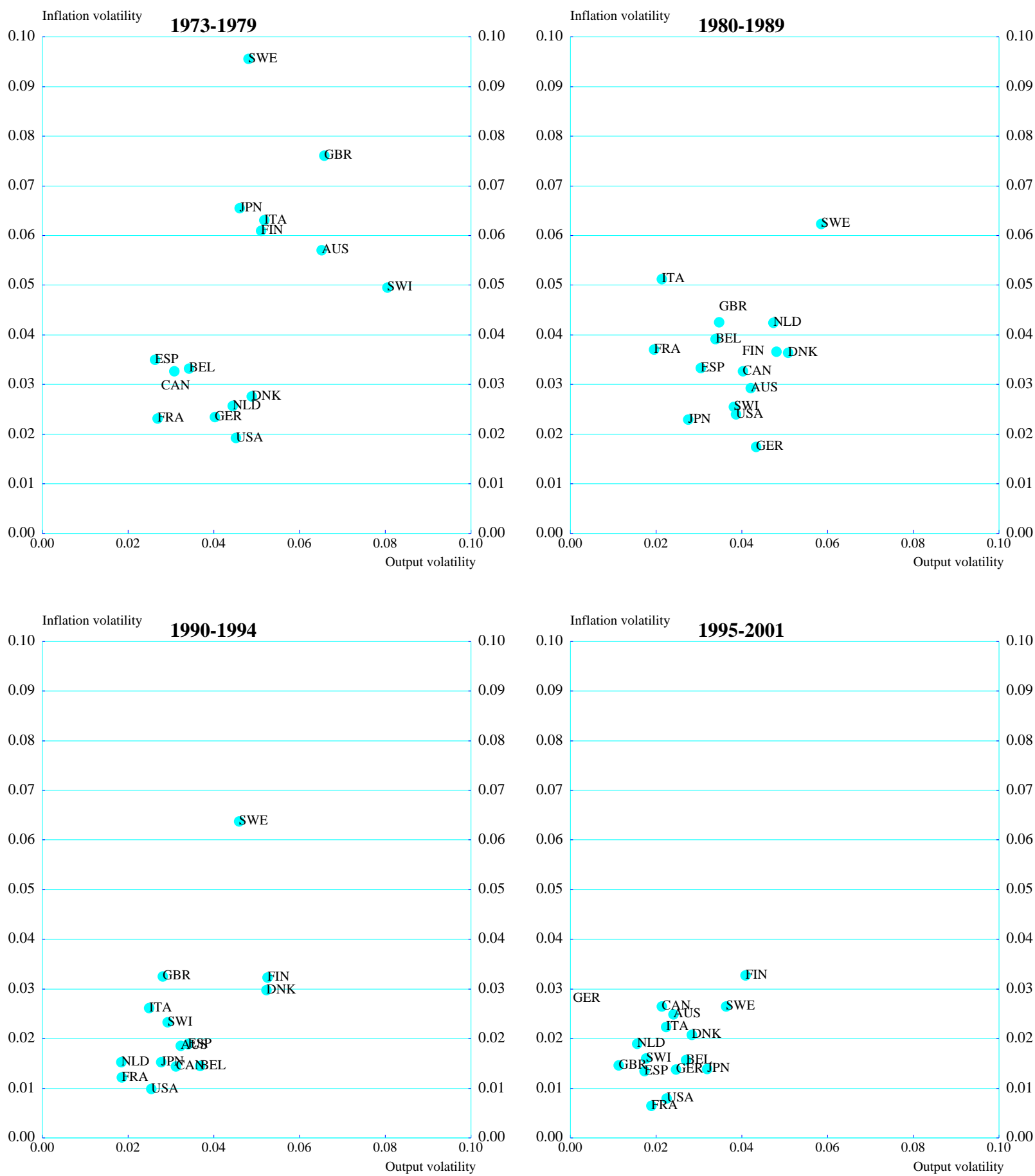

1. Volatility is measured by the standard deviation of the annualised quarterly GDP deflators and real GDP growth respectively. 
Figure 5. Cumulative output gap and core inflation in euro area countries (percentage points)
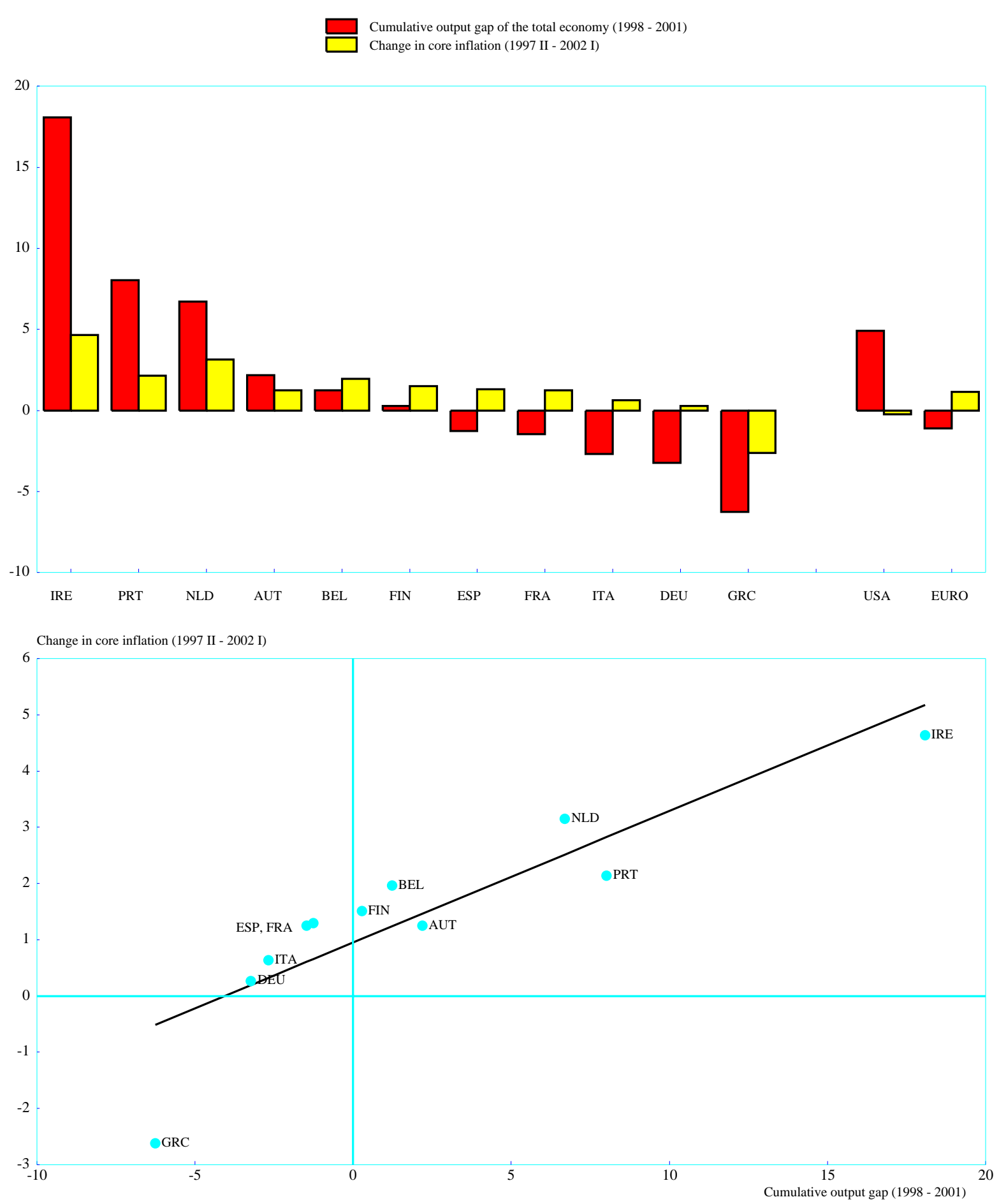

1. CPI excluding food, energy, alcohol and tobacco. Based on harmonised CPI for euro area countries (HICP). Source : OECD. 
Figure 6. Inflation expectations implied from indexed bonds

\section{United States}

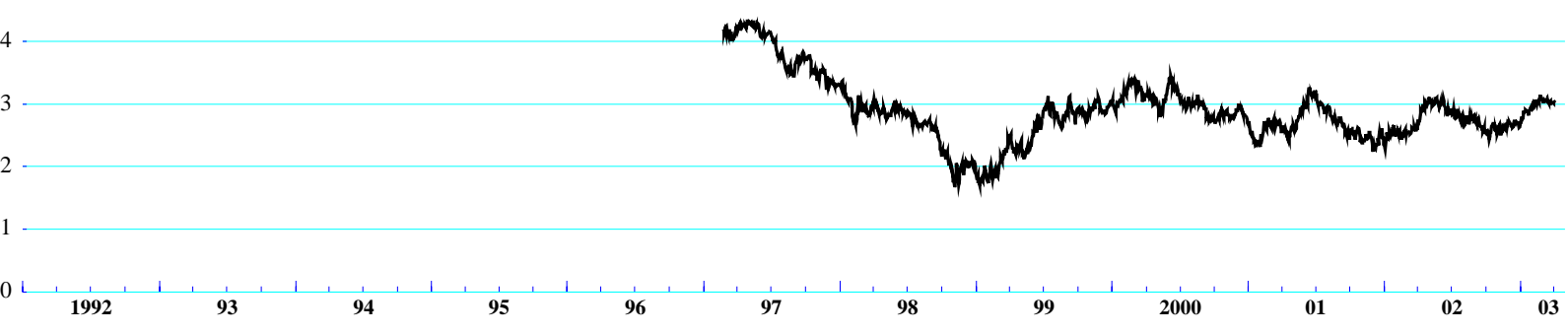

France
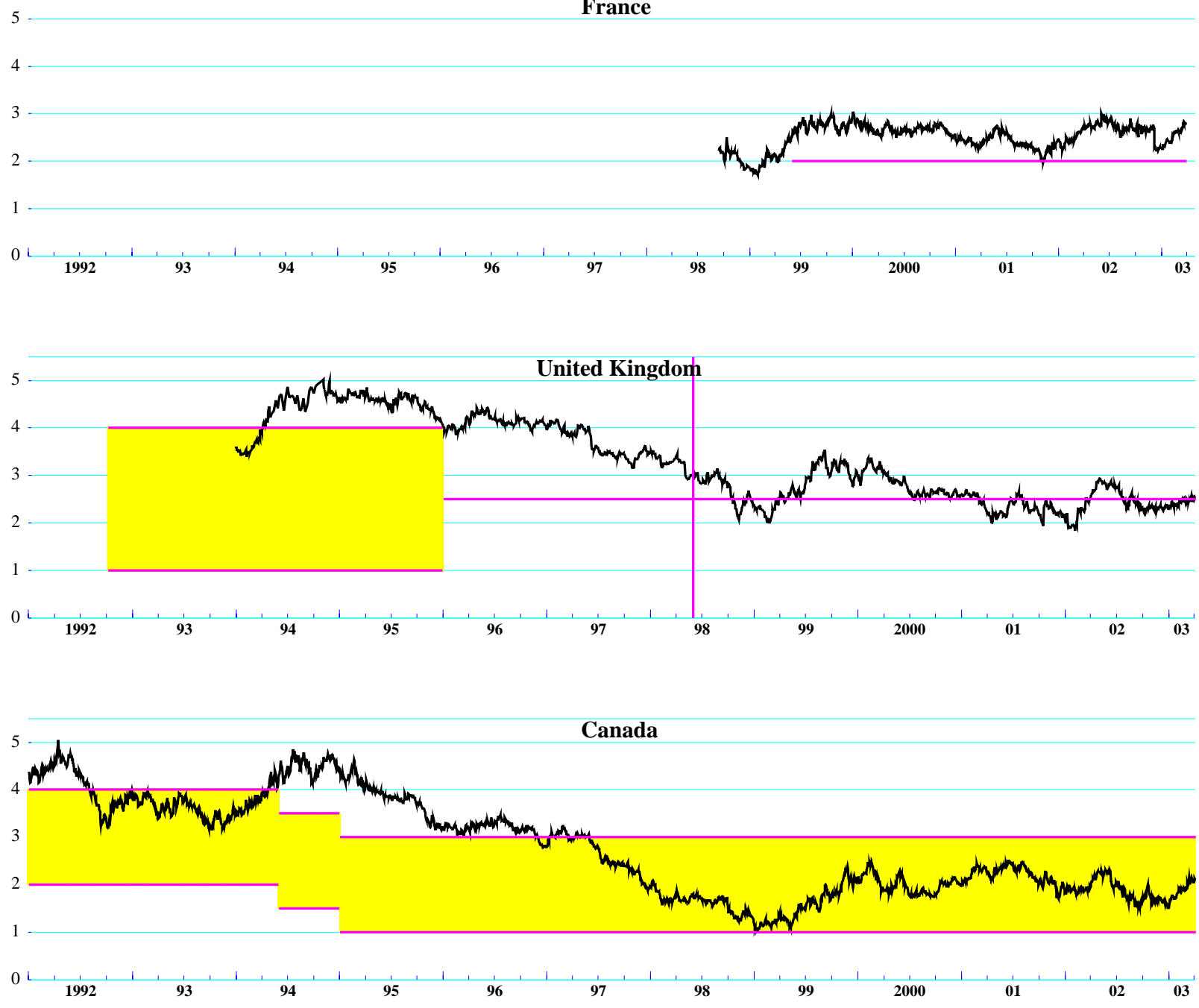

Note: Expected inflation implied by the difference between government benchmark bonds and inflation-indexed bonds.

Horizontal straight lines indicate inflation targets set by the respective central banks. For the United Kingdom the vertical line indicates the date

(1 June 1998) when the Bank of England obtained the operational responsibility for setting interest rates.

Source : Datastream, Agence France Trésor, Bank of Canada and OECD. 
Figure 6(con't). Inflation expectations implied from indexed bonds
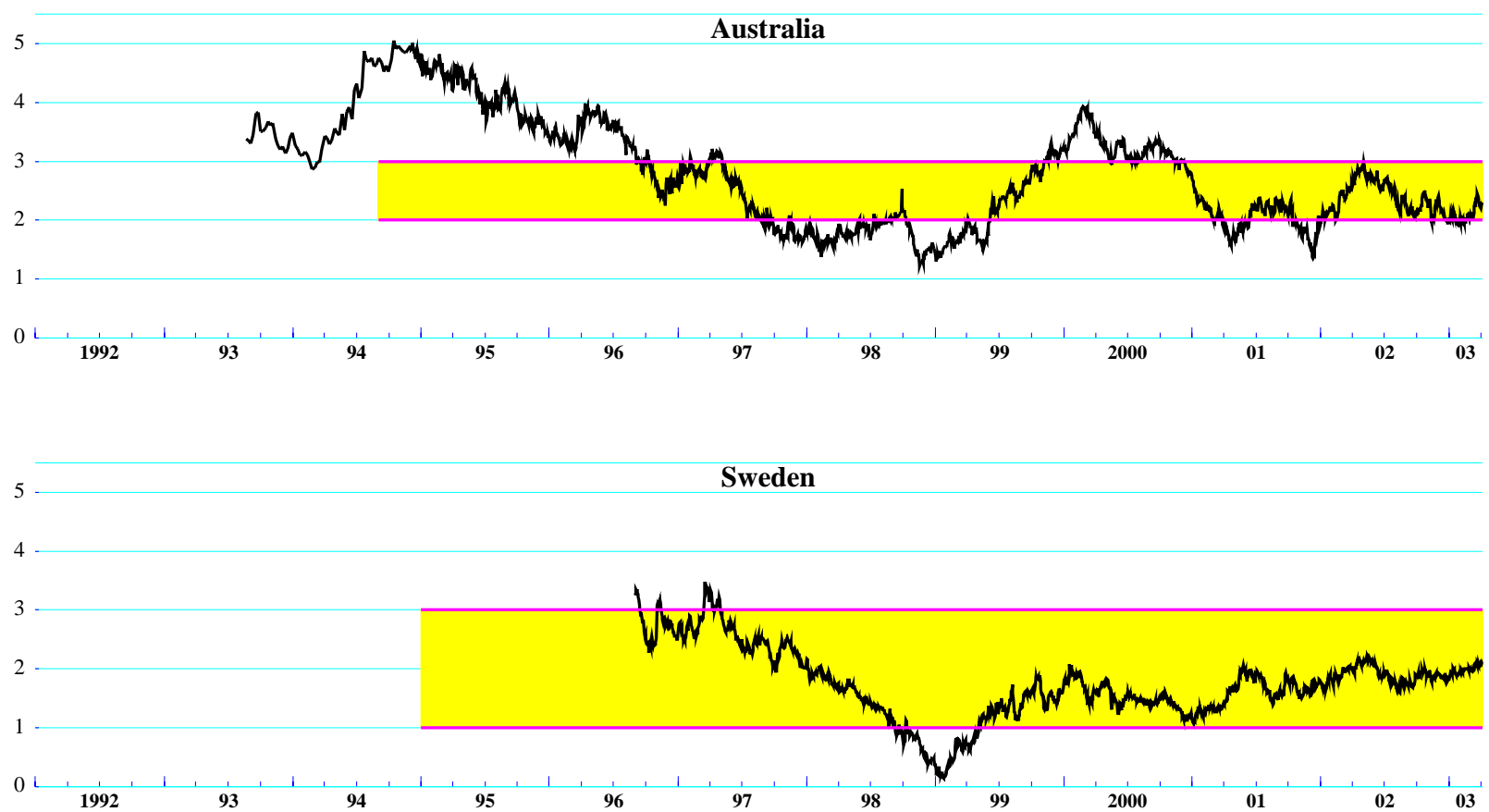

New Zealand

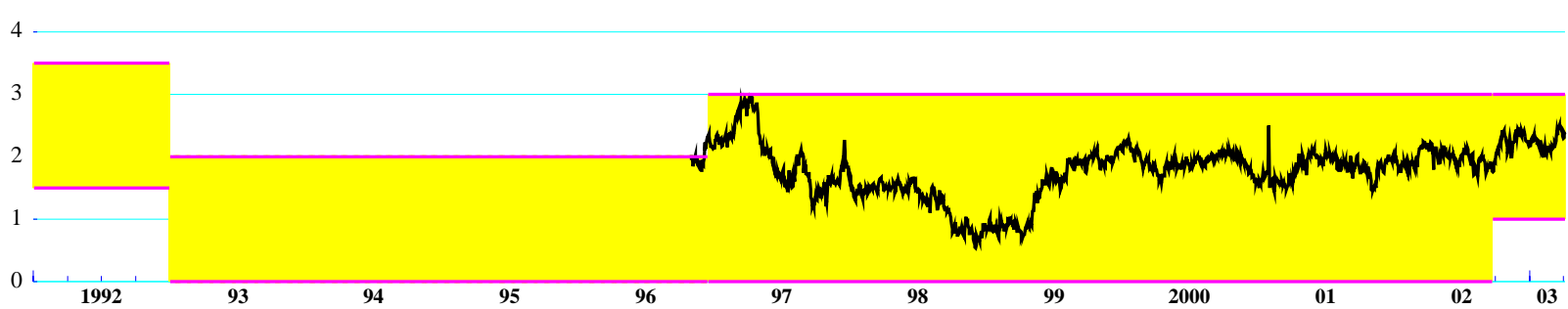

Note: Expected inflation implied by the difference between government benchmark bonds and inflation-indexed bonds.

Horizontal straight lines indicate inflation targets set by the respective central banks.

Source : Datastream, Bank of Canada and OECD. 
Figure 7. Equity price indexes

(Index January 1980=100, log scale)

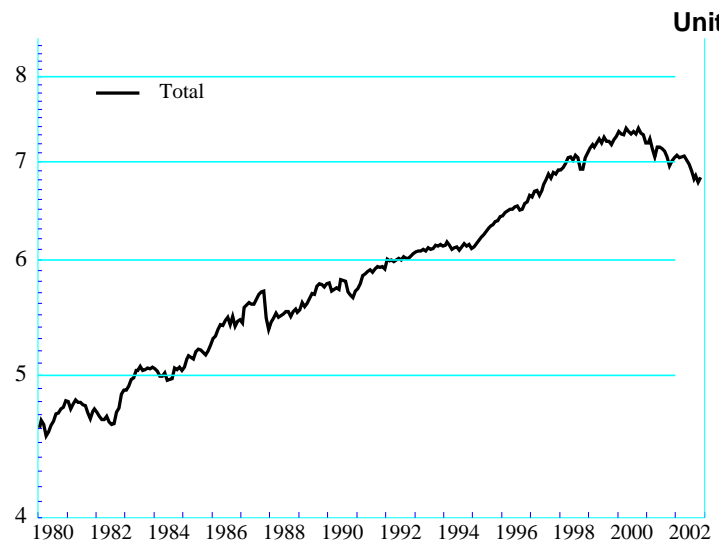

United States

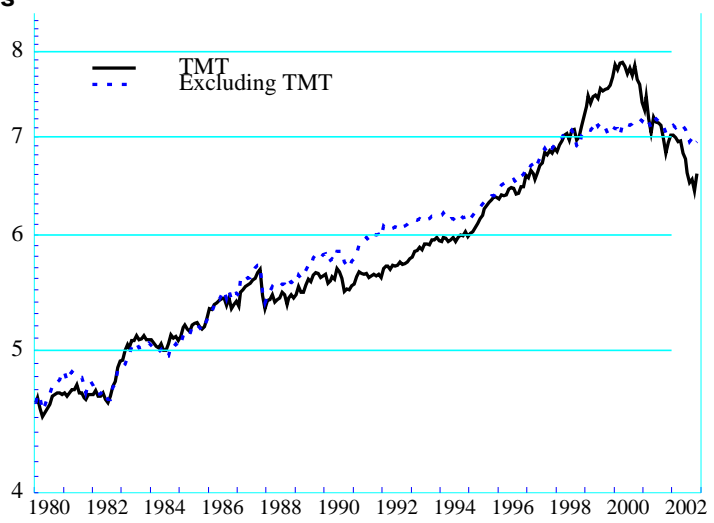

\section{Euro area}
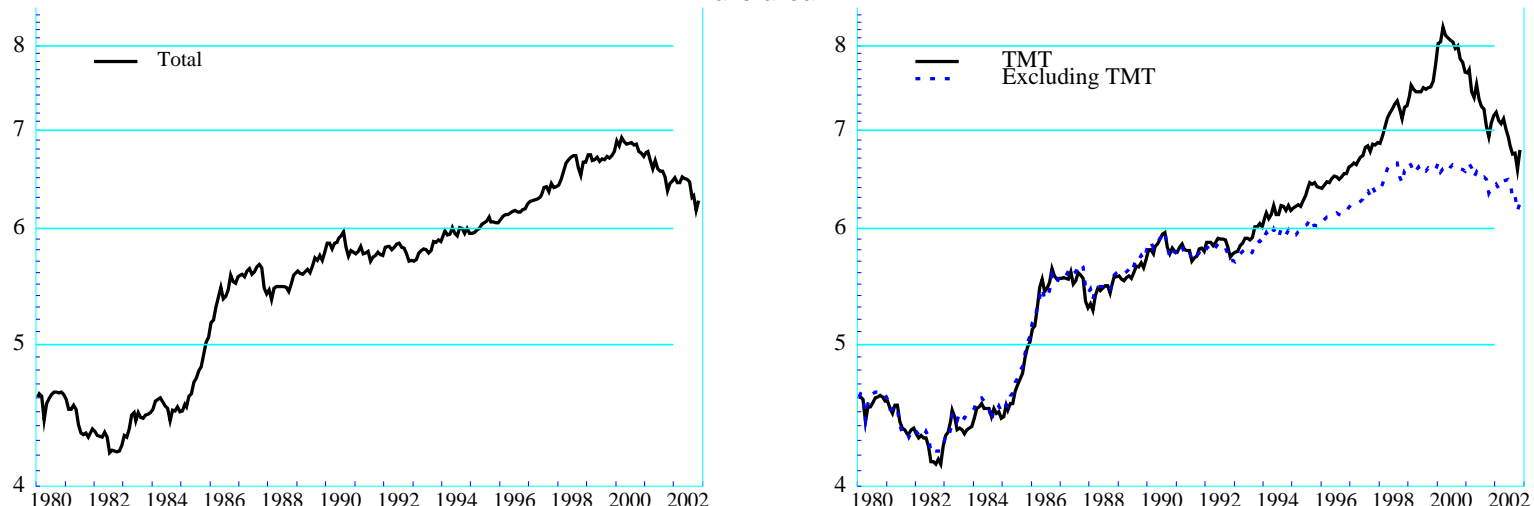

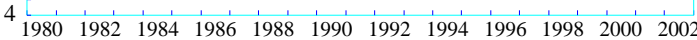

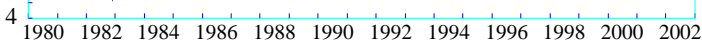

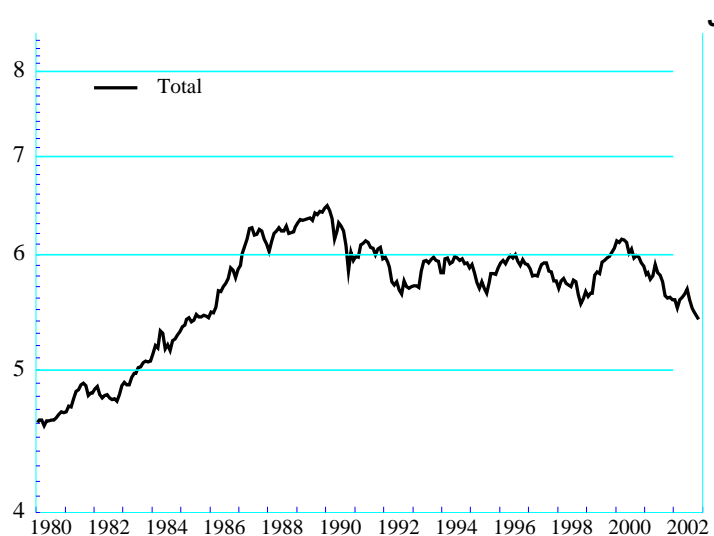

Japan

Note: TMT refers to Telecommunications, Media, and Technology.

Source: Datastream.

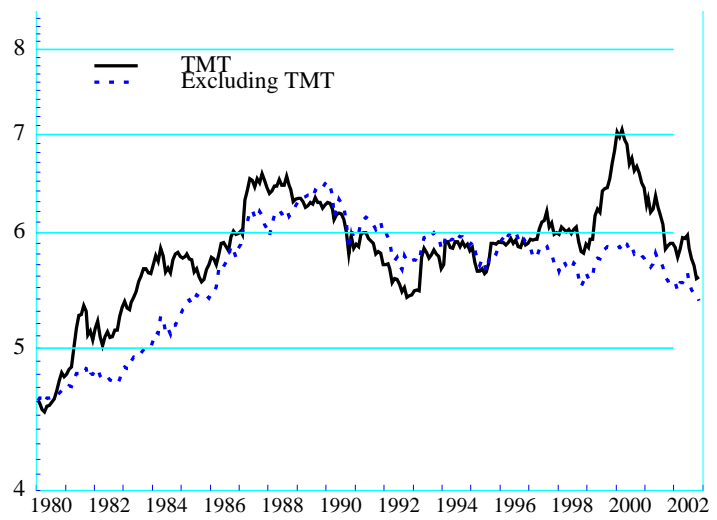


Figure 8. Real housing prices ${ }^{1}$

(1995=100)
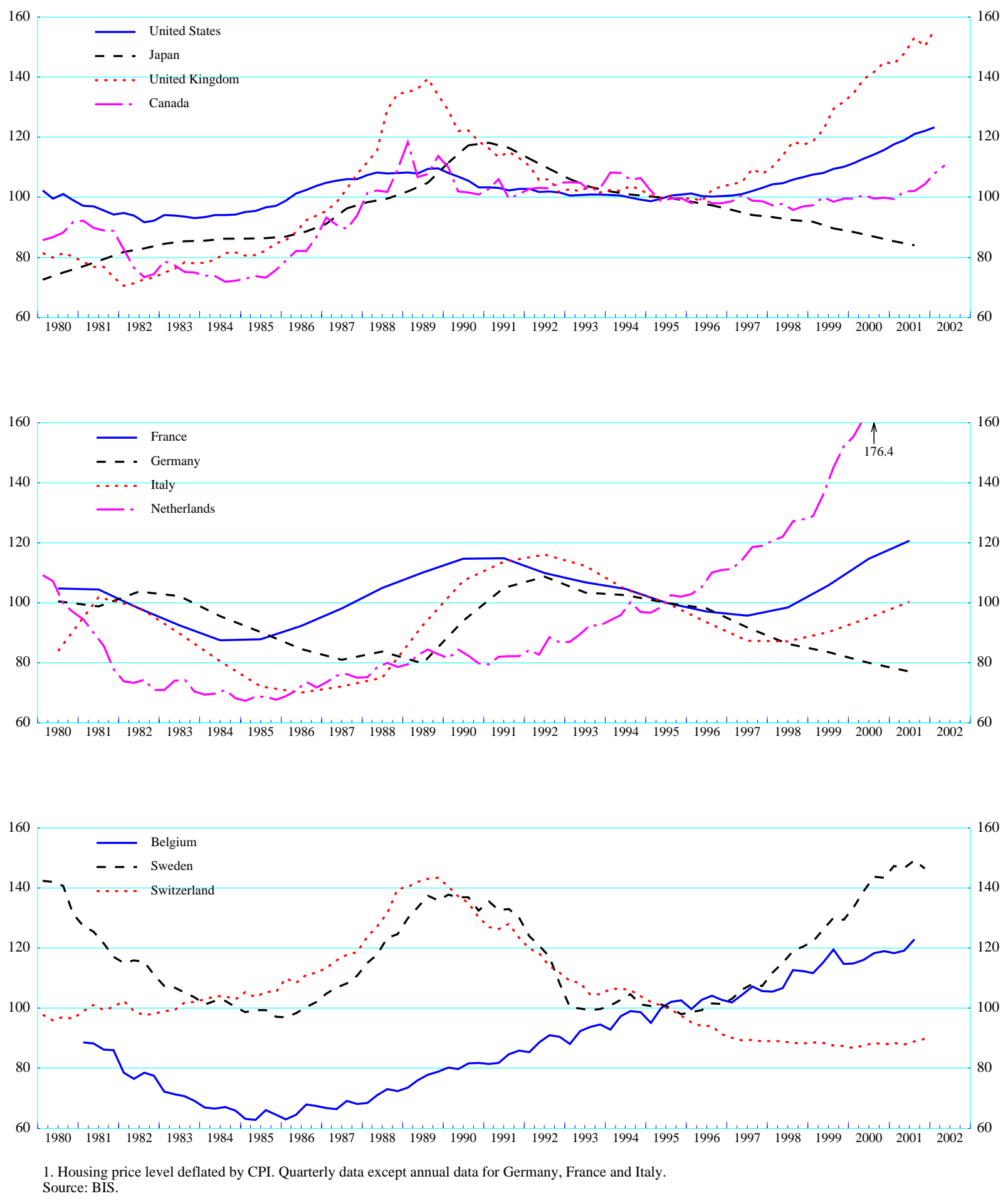
Figure 9. Fiscal balance positions and debt levels
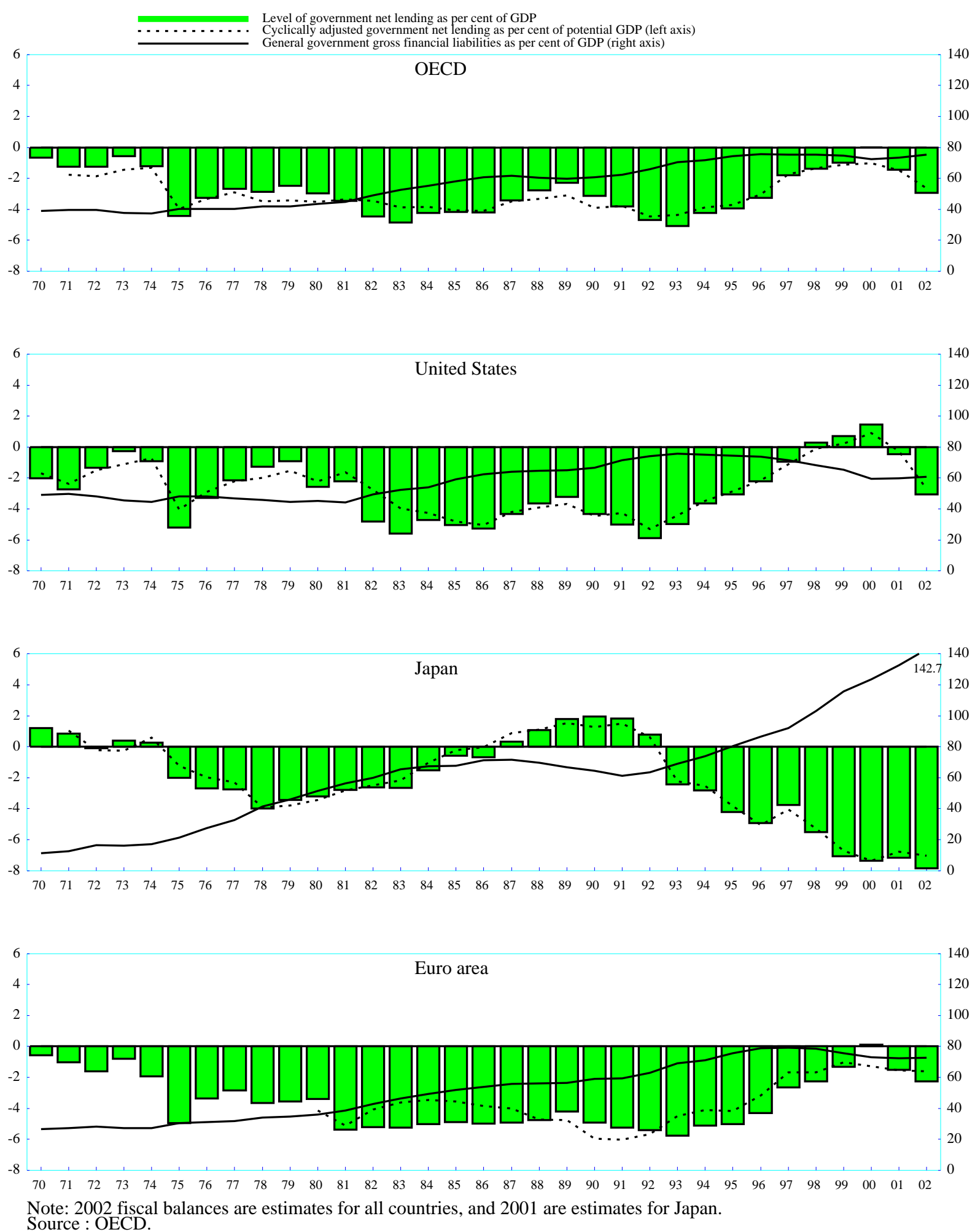
Figure 9(con't). Fiscal balance positions and debt levels
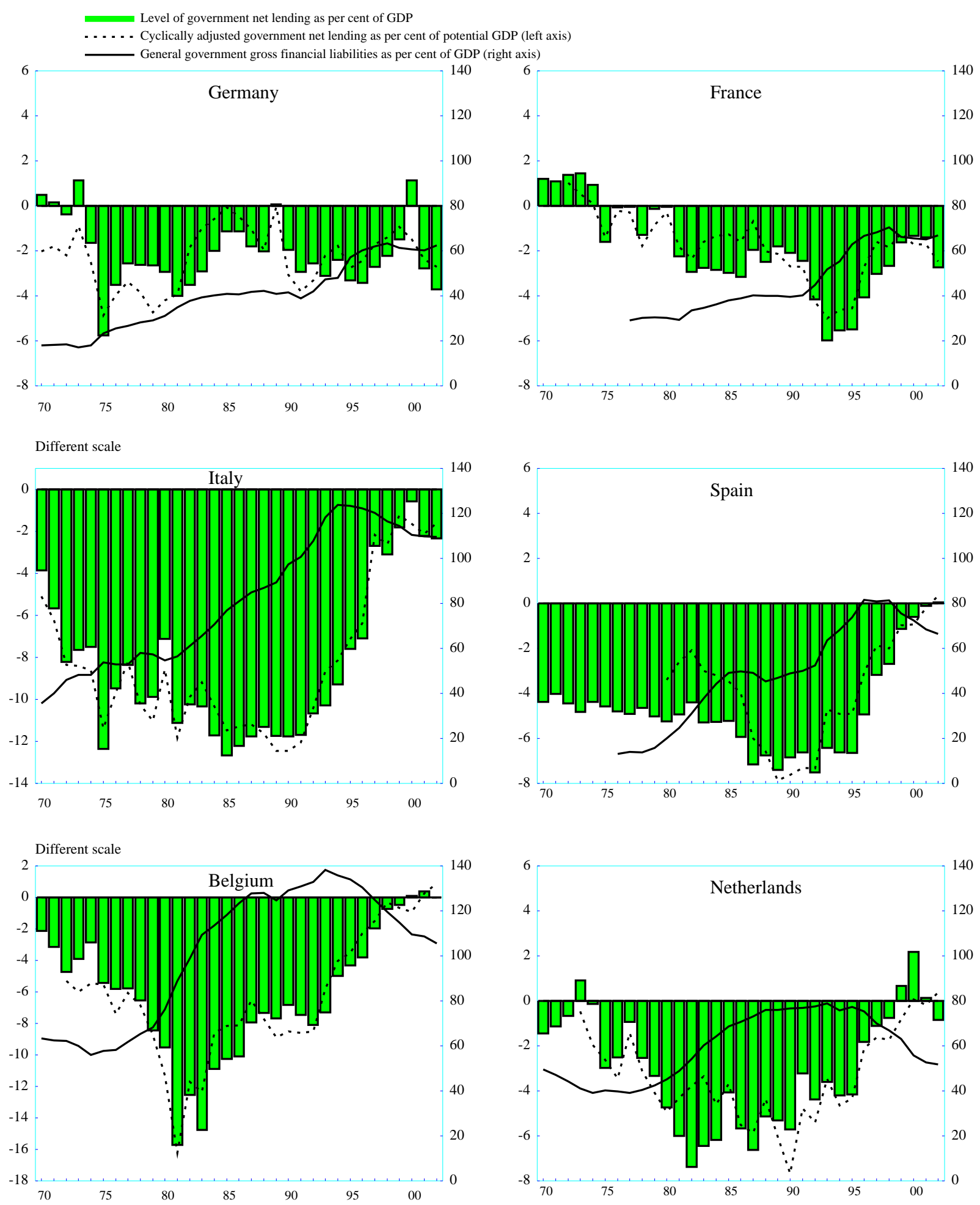

Note: 2002 fiscal balances are estimates for all countries. Source : OECD. 
Figure 9(con't). Fiscal balance positions and debt levels
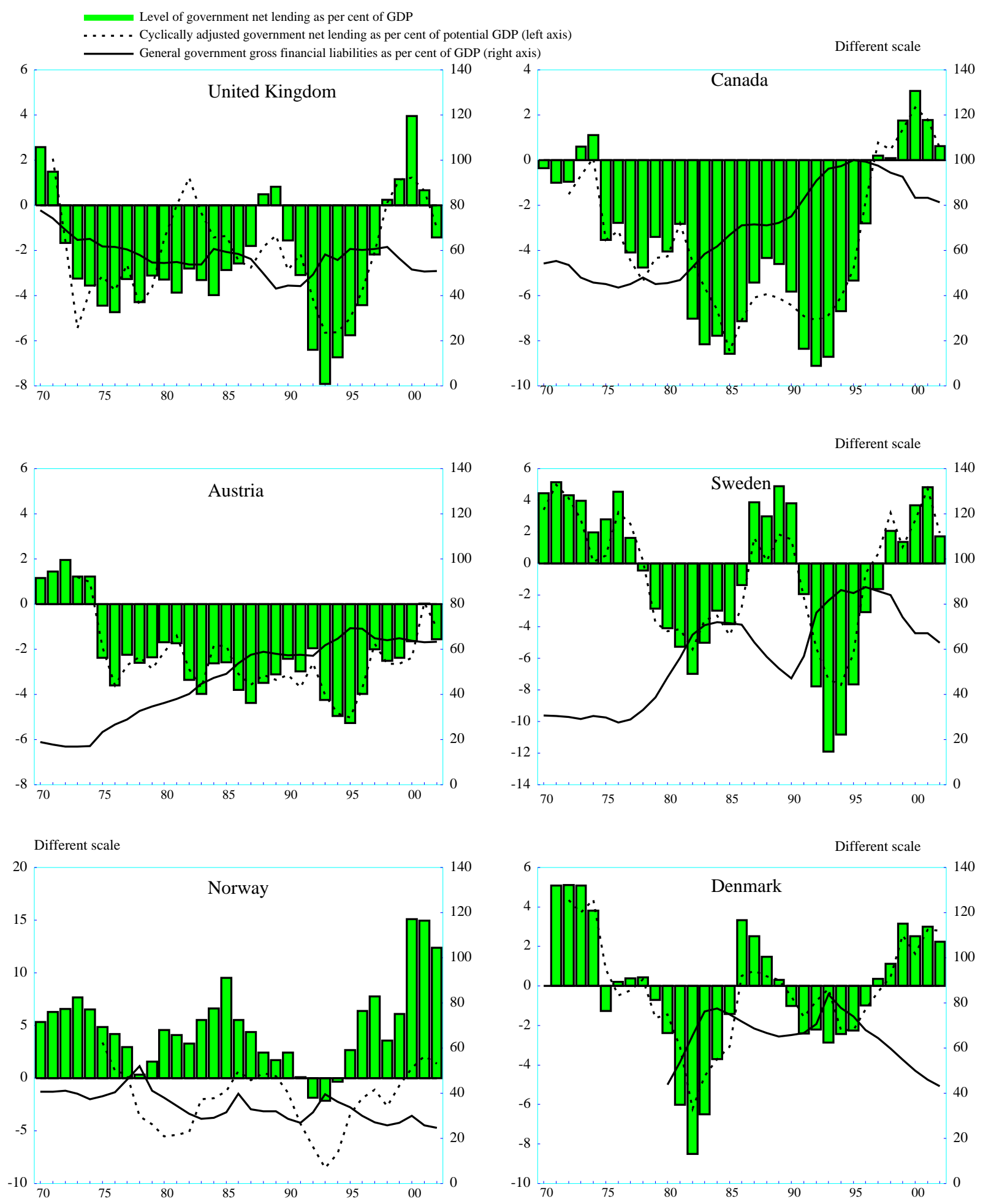

Note: 2002 fiscal balances are estimates for all countries. Source : OECD. 
Figure 9(con't). Fiscal balance positions and debt levels

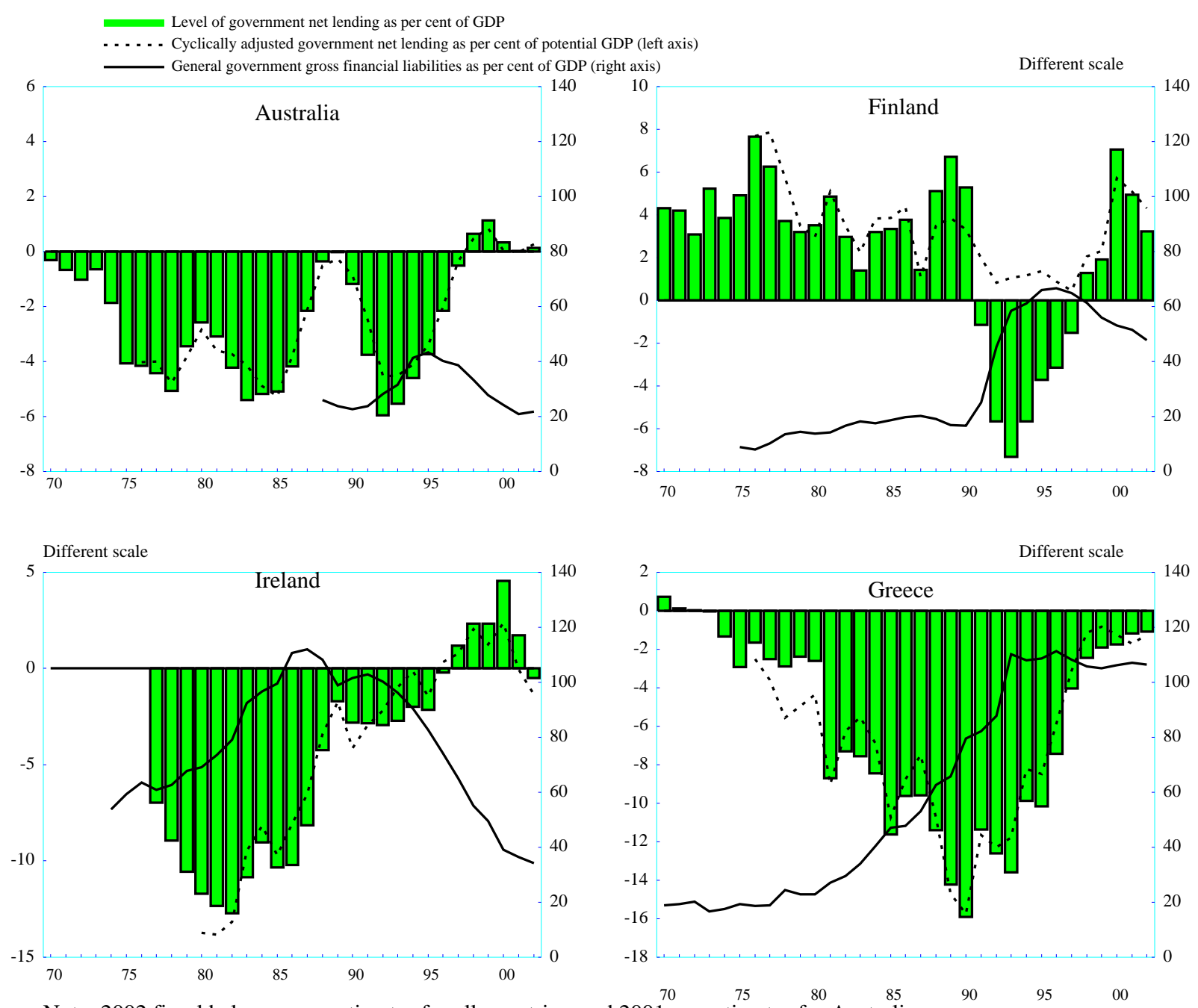

Note: 2002 fiscal balances are estimates for all countries, and 2001 are estimates for Australia.

Source : OECD. 
Figure 10. Output gaps and the change in the government structural balance
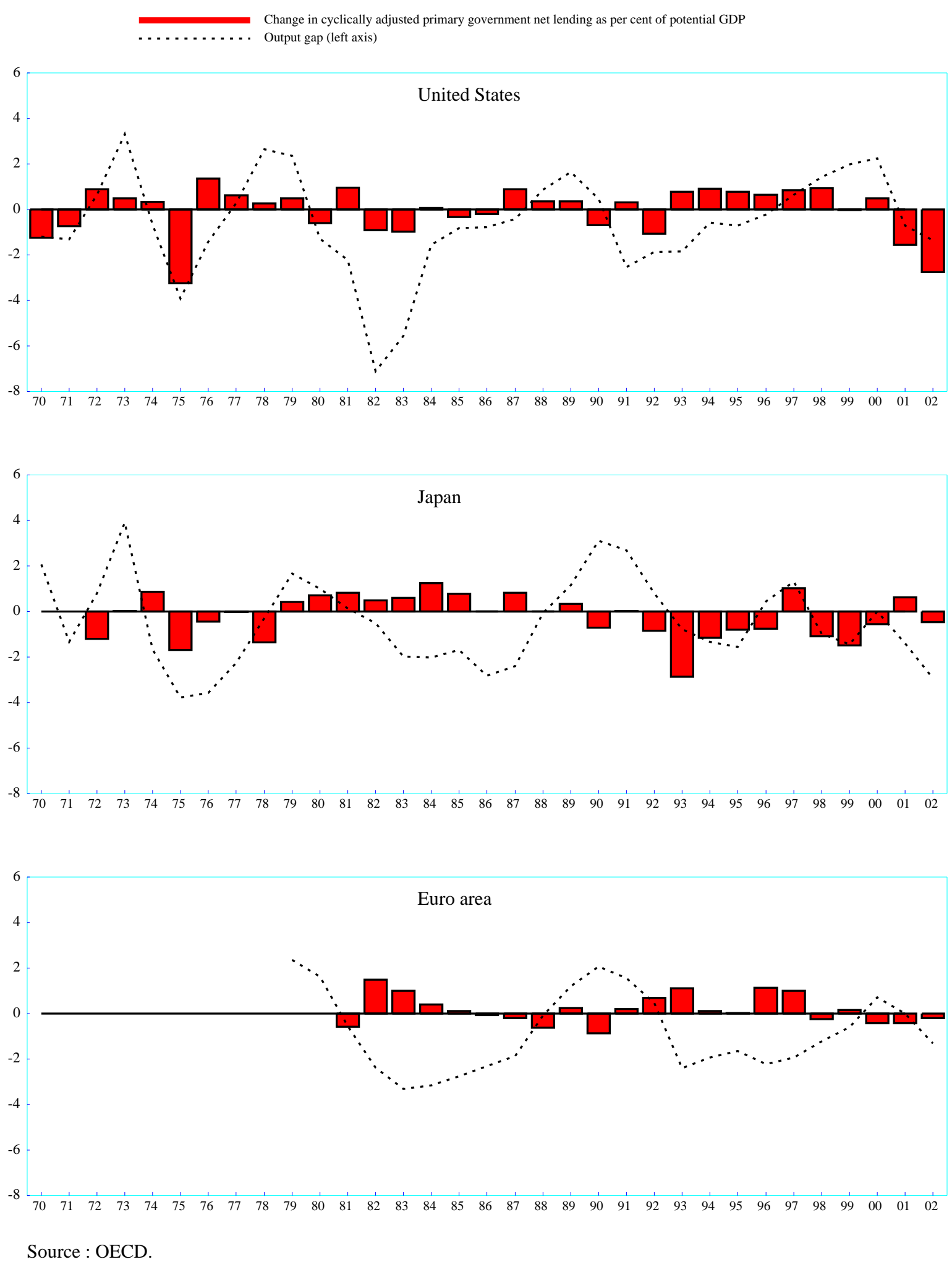
Figure 10(con't). Output gaps and the change in the government structural balance
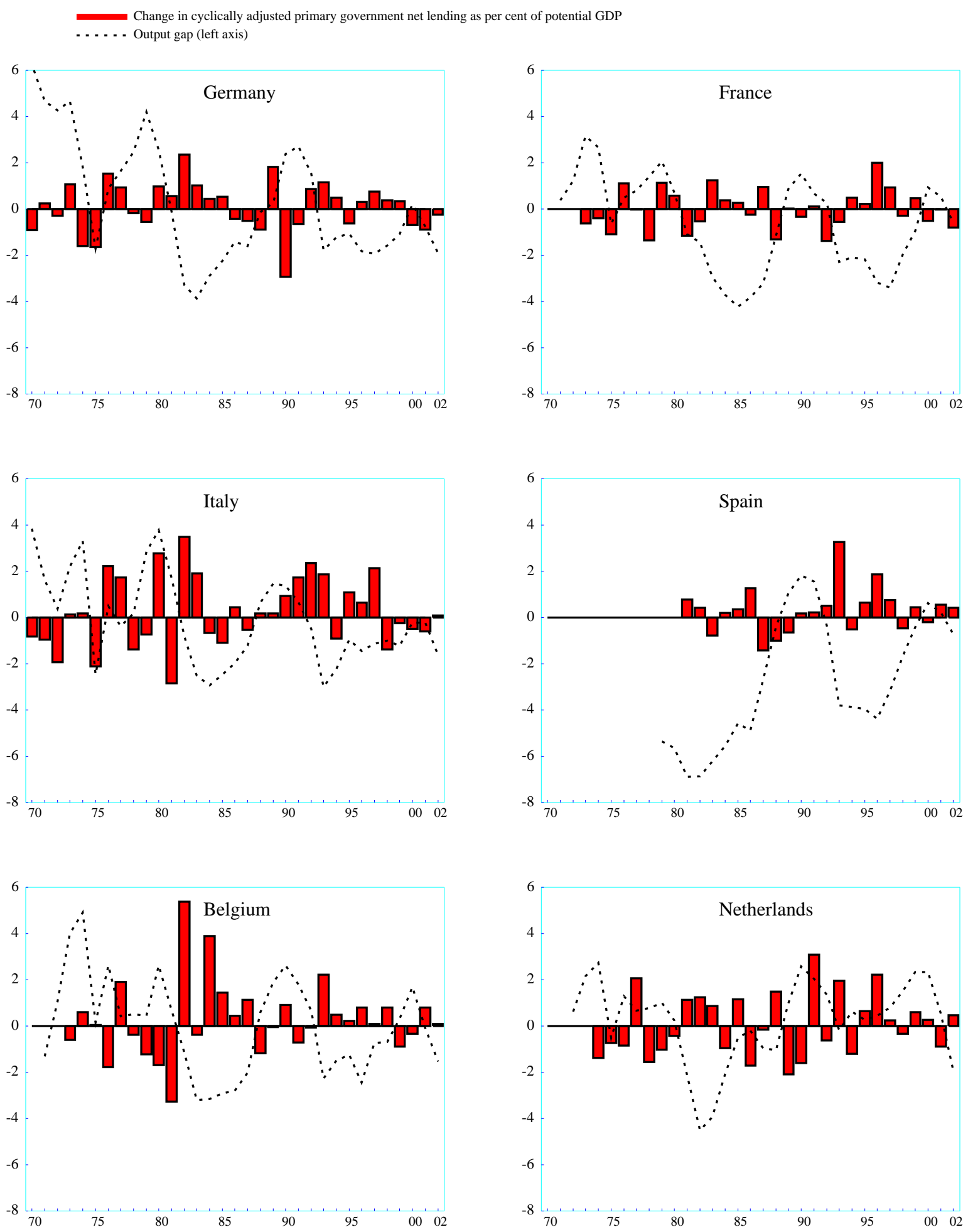

Source : OECD. 
Figure 10(con't). Output gaps and the change in the government structural balance
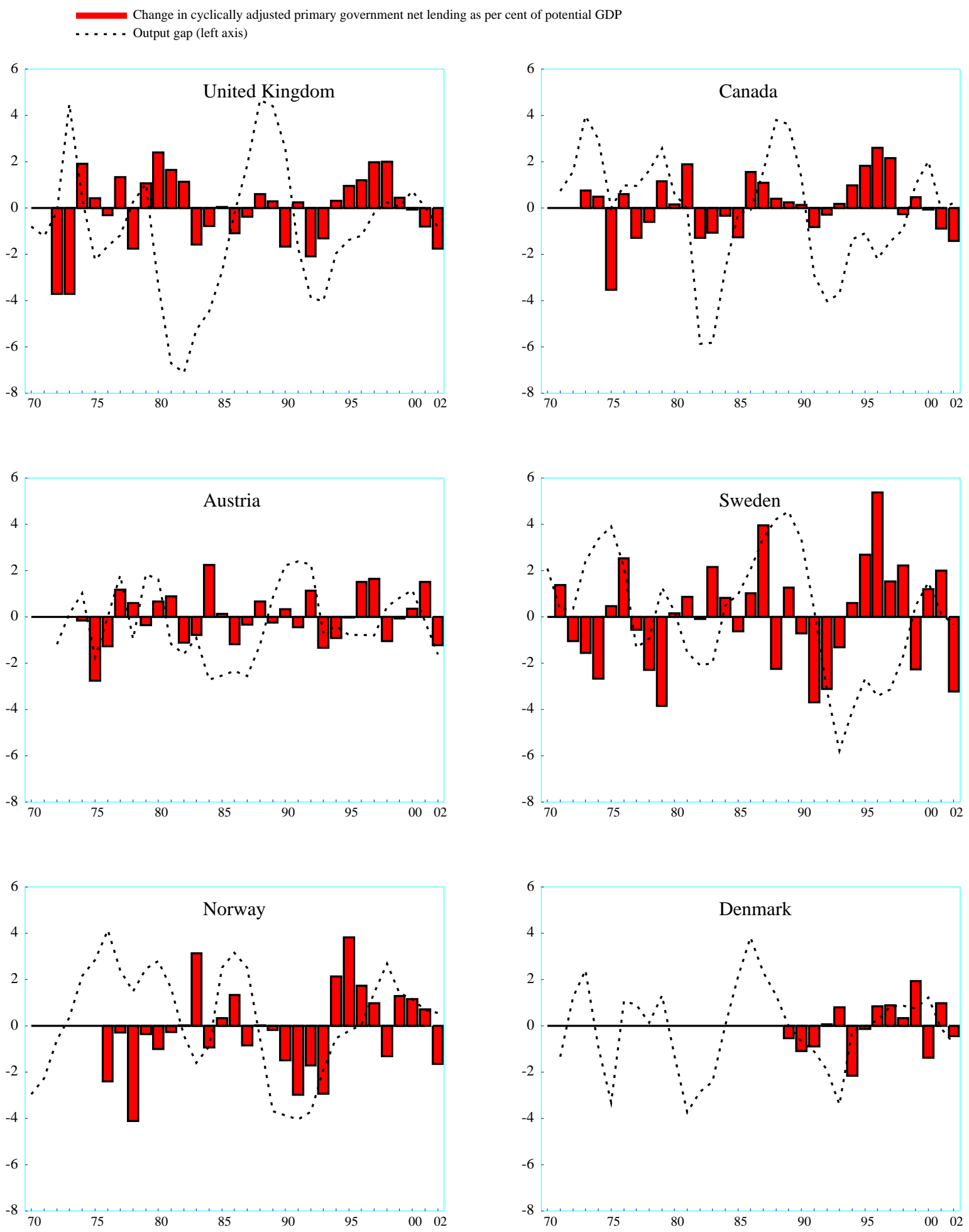

Source : OECD 


\section{RECENT ECONOMICS DEPARTMENT \\ WORKING PAPERS}

The full series of Economics Department Working Papers can be consulted at www.oecd.org/eco/Working_Papers/

352. Regulation and Investment

(March 2003) Alberto Alesina, Silvia Ardagna, Giuseppe Nicoletti and Fabio Schiantarelli

351. Discretionary Fiscal Policy and Elections: The Experience of the Early Years of EMU

(March 2003) Marco Buti and Paul van den Noord

350. The US Health System: An Assessment and Prospective Directions for Reform

(February 2003) Elizabeth Docteur, Hannes Suppanz and Jaejoon Woo

349. The Effectiveness of Public Expenditure in Portugal (February 2003) Chiara Bronchi

348. Comparative Analysis of Firm Demographics and Survival: Micro-Level Evidence for the OECD Countries (February 2003) Eric Bartelsman, Stefano Scarpetta and Fabiano Schivardi

347. Regulation, Productivity and Growth: OECD Evidence

(January 2003) Giuseppe Nicoletti and Stefano Scarpetta

346. Public Expenditure Management in Poland

(December 2002) Andrew Burns and Kwang-Yeol Yoo

345. Enchancing the Effectivesness of Public Expenditure in Sweden

(December 2002) Deborah Roseveare

344. The Decline in Private Saving Rates in the 1990s in OECD Countries: How Much Can Be Explained by NonWealth Determinants

(November 2002) Alain de Serres and Florian Pelgrin

343. Enhancing the Effectiveness of Public Expenditure in Norway

(October 2002) Isabelle Joumard and Wim Suyker

342. Productivity and Convergence in a Panel of OECD Countries: Do Regulations and Institutions Matter? (September 2002) Stefano Scarpetta and Thierry Tressel

341. Managing Public Expenditure: The UK Approach (August 2002) Paul van den Noord

340. The Brazilian Pension System: Recent Reforms and Challenges Ahead (August 2002) Marcos Bonturi

339. Challenges in the Mexican Financial Sector (August 2002) Marcos Bonturi

338. Coping with Population Ageing in Hungary (August 2002) Andrew Burns and Jaromir Cekota

337. Next Steps for Public Spending in New Zealand: The Pursuit of Effectiveness (July 2002) Dave Rae

336. Strengthening the Management of Public Spending in Hungary 
(July 2002) Jaromir Cekota, Rauf Gonenc and Kwang-Yeol Yoo

335. Automatic Stabilisers and Market Flexibility in EMU: Is There a Trade-Off?

(July 2002) Marco Buti, Carlos Martinez-Mongay, Khalid Sekkat and Paul van den Noord

334. The Economic Consequences of Terrorism

(July 2002) Patrick Lenain, Marcos Bonturi and Vincent Koen

333. Investment in human capital through post-compulsory education and training: Selected efficiency and equity aspects

(July 2002) Sveinbjörn Blöndal, Simon Field and Nathalie Girouard

332. Enhancing the Effectiveness of Public Spending in Switzerland

(June 2002) Isabelle Joumard and Claude Giorno

331. Competition and Efficiency in Publicly Funded Services

(June 2002) Jens Lundsgaard

330. Policy Pre-Commitment and Institutional Design: A Synthetic Indicator Applied to Currency Boards (May 2002) Marie-Thérèse Camilleri Gilson

329. The Role of Policy and Institutions for Productivity and Firm Dynamics: Evidence from Micro and Industry Data

(April 2002) Stefano Scarpetta, Philip Hemmings, Thierry Tressel and Jaejoon Woo

328. Improving the Efficiency and Sustainability of Public Expenditure in the Czech Republic (April 2002) Andrew Burns and Kwang-Yeol Yoo

327. Increases in Business Investment Rates in OECD Countries in the 1990s: How much can be explained by fundamentals?

(April 2002) Florian Pelgrin, Sebastian Schich and Alain de Serres

326. Sectoral Shifts in Europe and the United States: How They Affect Aggregate Labour Shares and the Properties of Wage Equations

(April 2002) Alain de Serres, Stefano Scarpetta and Christine de la Maisonneuve

325. Coping with Population Ageing in the Netherlands (March 2002) David Carey

324. Public Spending in Italy: Policies to Enhance its Effectiveness (March 2002) Alexandra Bibbee and Alessandro Goglio

323. Overheating in Small Euro Area Economies : Should Fiscal Policy React? (March 2002) Peter Hoeller, Claude Giorno and Christine de la Maisonneuve

322. Encouraging Environmentally Sustainable Growth in Austria (February 2002) Jens Høj and Andreas Wörgötter

321. Health Care Reform in Japan (February 2002) Yutaka Imai

320. Enhancing Expenditure Control with a Decentralised Public Sector in Denmark (February 2002) Steen Daugaard 